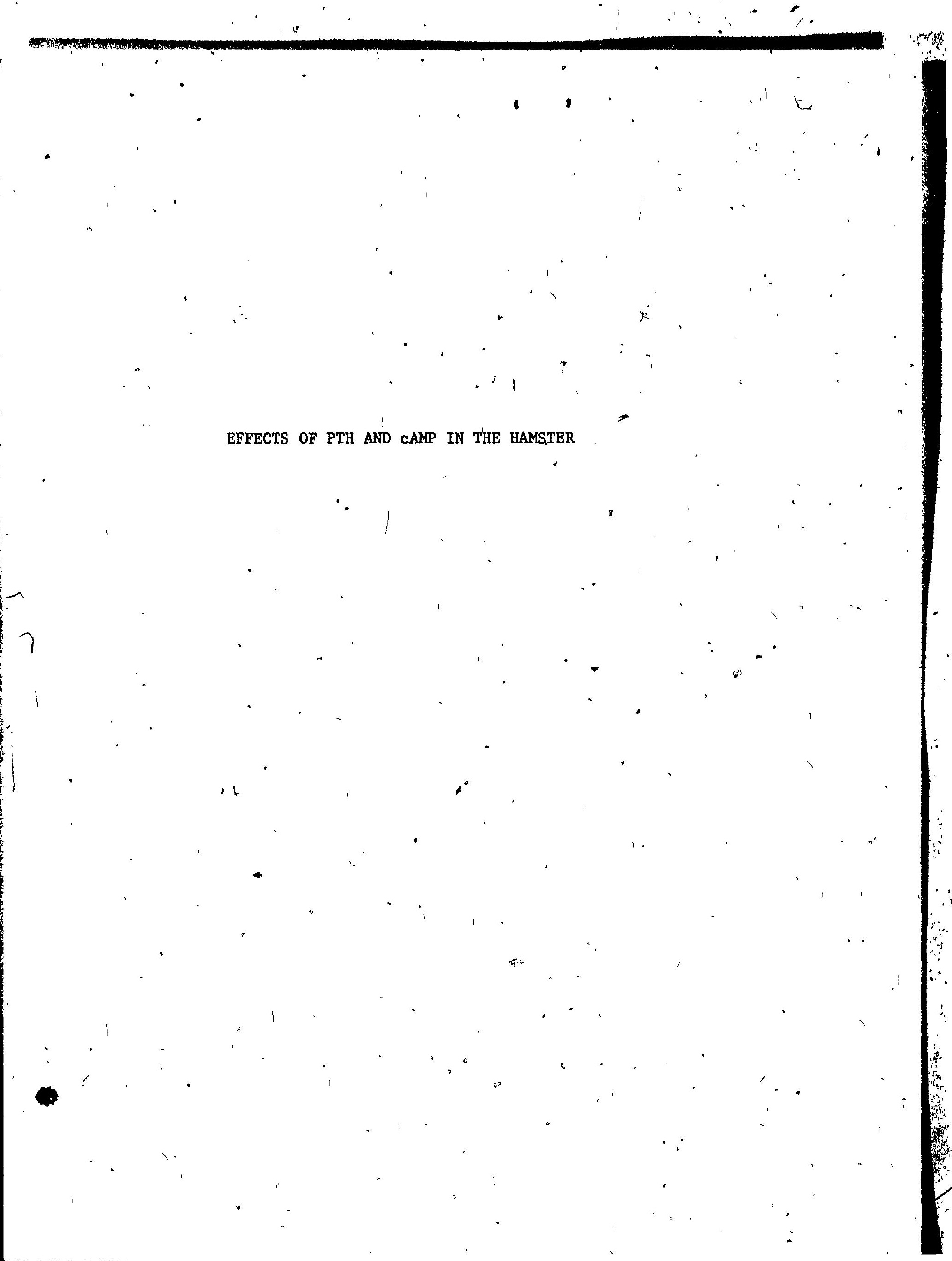


TRE EFFBCTS OP PTH, AHD caMp ON RENAL HANDLIAG OF :

CALCIUM, magnesium aNd PHOSPhate In the haMster

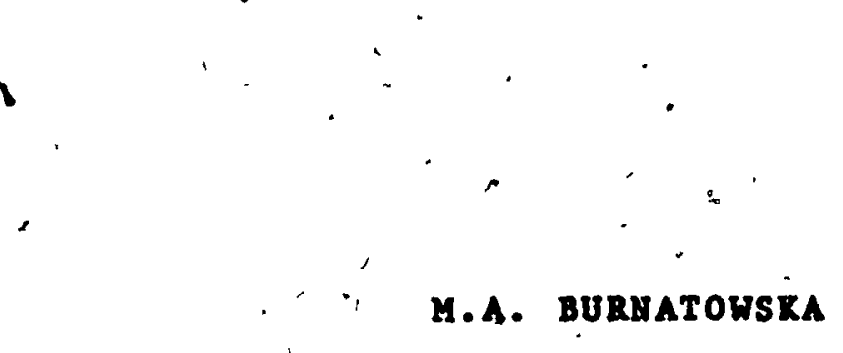

A thes1s gubaltced to the Faculty of Graduate studies and Research ln Partial Fulfilment of the Requirenents for the H. Sc: Degree

\section{Department of Phya10108y}

MeG111 Universiey

Karch 21, 1977

$-\sqrt{ }$

1$$
\sqrt{ }
$$ 


\section{ABSTRACT}

The objective of this sudy was to further-invest18 ate the effects and mechanism of action of parathormone upon the 'kidney and the role of caMp as a mediator of 1ta action on calclum and agracium reabeoxption. Hameters were used In these studies as thelr renal Ca transport was shown to be highly PTH seneltive. Clearance studlea were carried out in acutely thyroparathyroldectomised (TPTX) animals given $0.5 \%$ saline ip equal to $5 \%$ body weight. Acute TPTX led to a rise in fractional exeretion of calcium (FE Ca) $(2.8 \pm 1.0$ to $11.9 \pm 1.6 \%, p<0.001)$, FE $M_{8}(5.4 \pm 1.8$ to $18.7 \pm 2.5 \%, p<0.01)$ and was accompanied

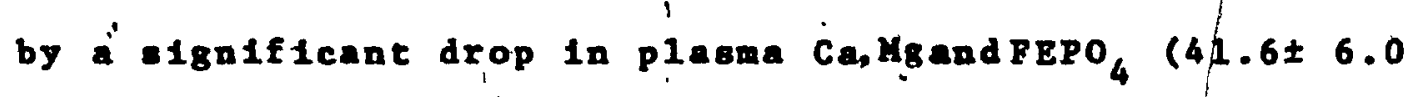
to $2,9 \pm 097$ p 0.02$)$.

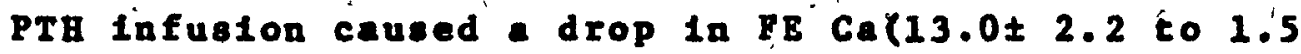
$\pm 0.32 \mathrm{p}<.001)$, $\mathrm{FE} \mathrm{Mg} \mathrm{(15.6 \pm 4.0} \mathrm{to} \mathrm{2.3 \pm 1.07p<.01),} \mathrm{and}$ a Ignificant rise In plase Ca and M8 $(3.6 \pm 0.2$ to $4.1 \pm$ $0.1 \mathrm{mEq} / 1 \mathrm{p}<0.01$ and $1.6 \pm 0.1$ to $2.3 \pm 0.1 \mathrm{mz} p<0.001$ reapectively). Infueton of cAMp caused a drop in FE Ca

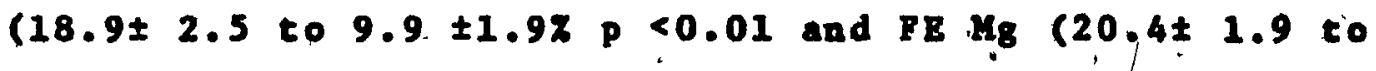
$13.2 \pm 2.5 p(0.01)$. Infusion of DBcAMP reduced PE Ca fron $17.5 \pm 2.9$ to $6.9 \pm 0.9(\mathrm{p}<0.01)$ and $\mathrm{FB} \mathrm{kg}$ from $21.5 \pm 3.6$ to 8.6.t1.27(p<0.01). There were no eignifleant affecte 

ABERGE

Le but de cette étude a été d'investiguer les effects et le mécanisme d'action de la parathormone (PTH) au nifveau du rein alnsi que le role de le cAMP combe médiateur de son action sur la réabsorption du calciup et du magnésium. Le transport rénal du $\because$ calcium étant très sensible a l'action de la PTH chez le hamster, des épreuves de clearance ont ẹté faites chez cette espèce. - Les animaux ont été thyroparathyroidectomisés (TPTX) de façon aigue et une solution aaline $0.5 \%$, f,j., ane dose equivalente a $5 \%$ du polds corporel a été administrée. La DPTX aigue provoque une élévation de l'excrétion fractionnelle (FE) du calcium(PE Ca 2.8 $\pm 1.0 \nsubseteq 11.9 \pm 1.6 \% ; p<0.001$ ), du màgnésium (FE Ng $5.4 \pm 1.8$ a $18.7 \pm 2.5 \% ; p<0.01$ ) accompagnée d'une chute significative du calcium et du magnésium plasmatiques; une chute de l'excrétion fractionnelle du phosphore a etế observée (FE $\mathrm{PO}_{4} .41 .6 \pm 6.0$ a $2.9 \pm 0.9 ; p<0.02)$.

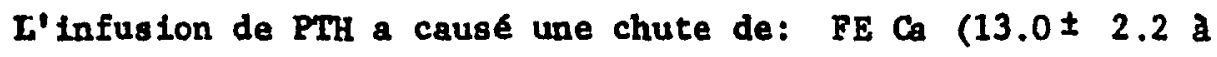
$1.5 \pm 0.3 \%, p<0.001), F E M(15.6 \pm 4.0 \mathrm{M} 2.3 \pm 1.0 \% p<0.01)$, et une elévation significative du calclum et magnésium plasmatiques $(3.6 \pm 0.2 \mathrm{a} .1 \pm 0.1 \mathrm{mEq} / 1, p<0.01$ et $1.6 \pm 0.1 \mathrm{a} 2.3 \pm 0.1 \mathrm{mg} / \mathrm{dl}$, p< 0.001)

L'infusion de CAMP a cause une chute de: $\mathrm{FE} \mathrm{Ca}(18.9 \pm 2.5$ a $9.9^{\prime} \pm 1.9 \%, p<0.01$ et $\operatorname{Fr}(20.4 \pm 1.9 \times 13.2 \pm 2.5 p<0.01)$.

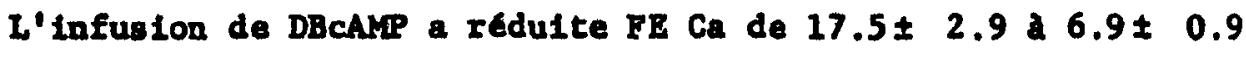
(p<0.001) fet de $21.5 \pm 3.6$ a $8.6 \pm 1.2 \%(p<0.01)$. Aucun 
effet significatif de l'cAMP et dẹ la DBCAMP`n'a éé observé sur le calcium ou le magnesium plasmatique total, L'effet phophaturique de la PIH n'a été demontré qu'avec la cAMP et la DBCANP.

Le debit urinaire et la filtration glomerulaire sont. demeurés s.tables chez tous 1 es groupes. Cette etude démóntre! pour $1 \mathrm{a}$ premiere fols, que la cAMP est le médiateur de la PIH sur le transport rénal du calcium, du magnesium et du phosphore. 
sit

i

ACKNOWLEDGEMENTS

This Investigation was carried out in the Renal and Electrolyte Division, Department of Medicine Royal Victor la Hospital and McGill University. I am Indebted to my supervisors Dr. J.H. Dirks and Dr. J.F. Seel and to Doctors C.A. Harris and R.A.L Sutton for their suggestions and encouragement during this study.

Also I wish to express my gratitude to Mrs. A. Redensek for her technical assistance and to Mrs. V. Doting and Mrs. J. Prut for typing of this thesis. 
Sone of the work described in this thesis appeared in the following manuscripte:

1. Evidence for Parathyrold Hormone (PTH) enhancenent of calcium and magnesium reabsorption in the cerminal nephron segment of the Hamster. Harris, C.A., Burnatowaka, M., Sutton, R.A.L., Dirks, J.H., Clinícal Research 24 p.401A (Abstract) 1976.

2. Effects of PTH and CAMP on renal handilng of calclum, magnesium and phoaphate in the haseter. Burnatowska, M.A., Harra, C.A., Sutton, R.A.I., Dirka, J.H. Abstract in the Am. Soc . Neph. 9 th Anqual Meeting, $2 A$.

3. Effects of PTH and CAMP on renal handilng of calcium, magnesium and phosphate in the hanser. Burnatowska, M.A., Harris, C.A., Sutton, R:A.L., Dirks, Jíb. Paper In preparation. Paper in pre 
TABLE OF CONTENTS

PAGE

ABBREY IATIONS

-

CHAPTER I

CHAPTER II

A)

LIST OF TABLES \& PIGURES

INTRODUCTION AND STATEMENT OF PURPOSE

1

BISTORICAL REVIEW OF LITERATURE

GENERAL MATURE OF THE TUBULAR TRANSPORT OP DIVALENT ELECTROLYTES

1. Phosphate

2. Calciun

3. Magnesium

FACTORS INRLUENCING RENAL TRANSPORT BLECTROLYTES

B)

Role of Parathyroid Hormone

1.

Chen 1atry

11.

Synthesis and degradation

111.

Effects of parathyrotd hormone on renal handling of electroly.tes

a.

Effects of PTH on renai phosphate handling transport

b. effects of PTH on renal calclum handling

c. Effects of PTH on renal magnesium handling

2.

Role of CAMP in the wechanisn of action of PTH in the renal tubular transport of electrolytes

1.

cAMP generation in the kidney

11.

Hormone Neceptors In the kldney

111.

Adenj $1_{/ /}$cjelase

Iv.

Proteln klnase 
TABLE OF CONTENTS (CON'D):

a. In vitro otudies 35

b. In vivo sudies

In vivo stodes

CHAPTER III GOLDEN SYRİAN HAMSTER(MESOCRICETUS AURATUS) 37 MODEL FOR THE INVESTIGATION OF THE MECHAN'ISM OF PTH ACTION ON THE RIDNEY

CHAPTER IV METEODS

1. Anfaal preparation

2. Experţmental protocol

3. Chemtcal methoda

4. Methods of analysis

CHAPTER $V$ RESULTS

1.

Comparison of intact and TPTX hamsters

43

2. Effects of PTH and cyclic nucleotides in TPTX hamsters.

1.

Hemodynam le changes,

44

11.

Changes in the handling of calcium

111. chranges in the handilng of magnesium

16.

Changes in the handling of phosphate

45

$\mathbf{v}$

Effecte of DBCAMP AND $\mathrm{CaCl}_{2}$ Infueion

CHAPTER VI DISCUSSION 


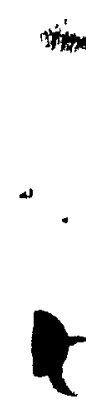

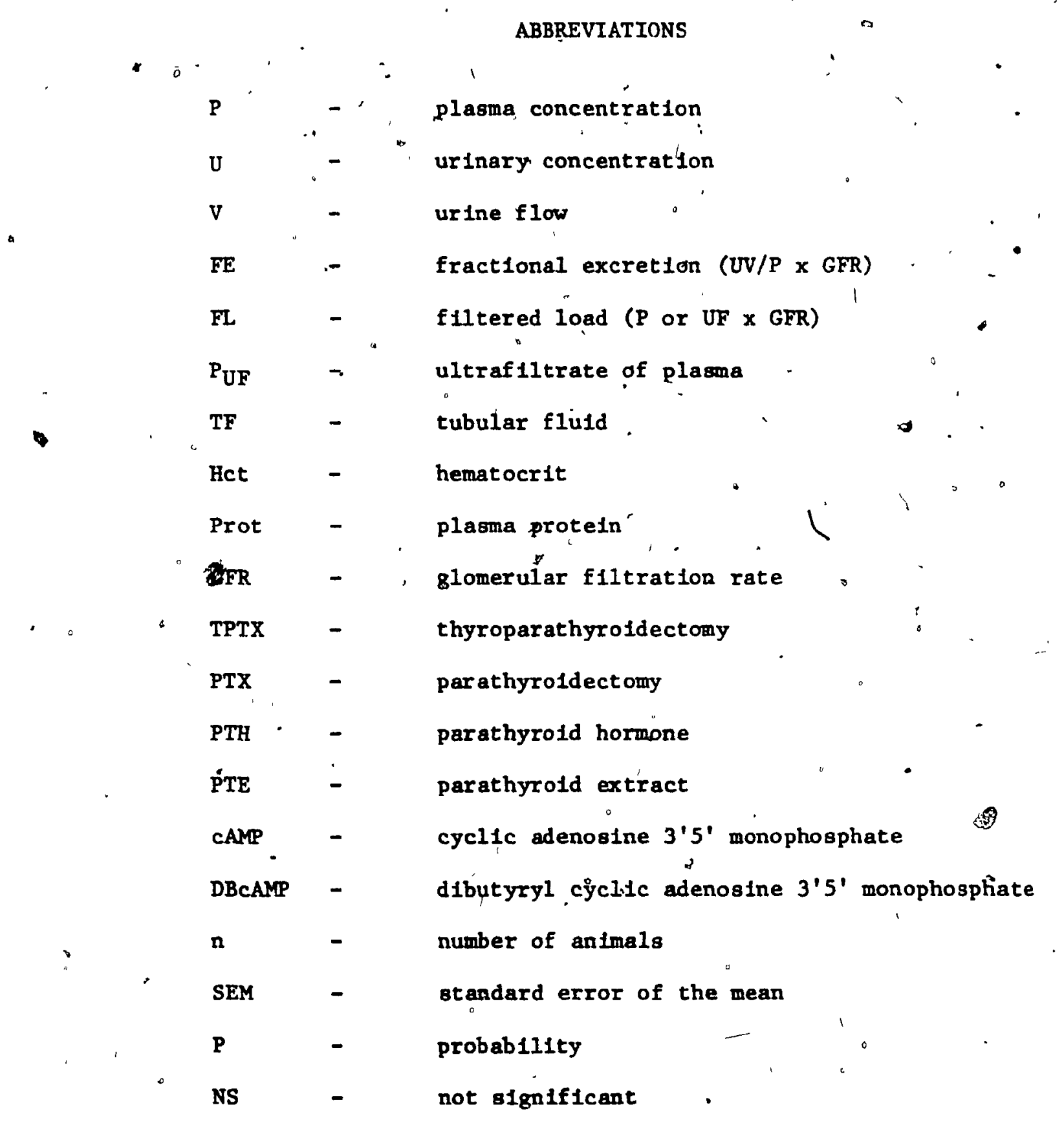


LIŚT OF TABLES AND FIGURES

TABLES:

(4)

PAGE

1.1 - Comparison of intact and TPTX haneters.

II - Hemodynamic effects of PTH, cAMP and DBCAMP:

- III- Effects of PTH, CAMP and DBCÁMP on renal -

calcium handling.

IV - Bffects of PTH, CAMP and NDBCAMP on renal magnesium handilng.
V - Effects of PTH, cAMP and DBcAMP on renel phosphate handiling.
$\checkmark$ - EEfecta of PTH, cAkP and DBCAMP on renel

VI - Tffects of DBCAMP on renal handilng of calciup and magnesiun with $1.6 \mathrm{me} / 1$ calclum chloride Infusion in the experimentel phase.

\section{FIGURBS:}

1. Effects of PTH, CAMP and DBCAMP Infusion on

fractional calclum excretion.

2. Effects of PTH cAMP and DBCAMP on fractional magnesium excretion. $\rightarrow$ 3. Effect of PTH, cAMP and DBCAMP on fractional
phosphate excretion. 
CHAPTER I - INTRODUCTION AND STATEMENT OF PURPOSE.

The effecta of parathyrold hormone on the renal handI1ng of eiectrolyces have been a subject of considerable Investigation over several decades. The hornone has been shown to Increase urinary excretion of phoaphate (Greenwald 1925, Ellaworth 1935, Puflean et al. 1960, strlckler et al. 1964, Agus et"al. 1971, Andel et al. 1970, Anlel et al. 1974, Brunette 1974) blcarbonate (Nord1n et al. 1960, Hellman et al. 1965, Muldowney et al. 1971) and sodiun (Ellsworth 1935. Be1liman et a1. 1965, Amlel et al. 1970) and to decrease that of calciun, (Talmage et al. 1954, Kleeman et a1. 1961, Wldrow Levlnsky, 1962, Sutton et al. 1976) and magnealum (McIntyre 1963, Messry et a1. 1969): The phosphaturic effect of PTH 1s though tón be mediated by cAMP. A rise in urinary cAMp after adninistration of PTH has been obseryed In TPTX rate (Chese and Aurbach 2967) as well as in humans (Kamsinsky et a1. 1970), and PTH benolelve adenjl-cyclase has been iocalised in the renal cortex (Chase and Aurbach 1968), and more recently to apecific porolons of the nephron. (Chabardes al. 1975). The Interaction of PTH with opecific receptors (Sutcilffe et a1. 1973, D1Be1la et al. 1974) 18 felt to lead to otinulation of adenji-cyclare at the contralutinal ceil éenbrane:(shiats et 1. 1975), generation of Intracellular cAkP, (Aurbact 1972, Me1son 1970) 


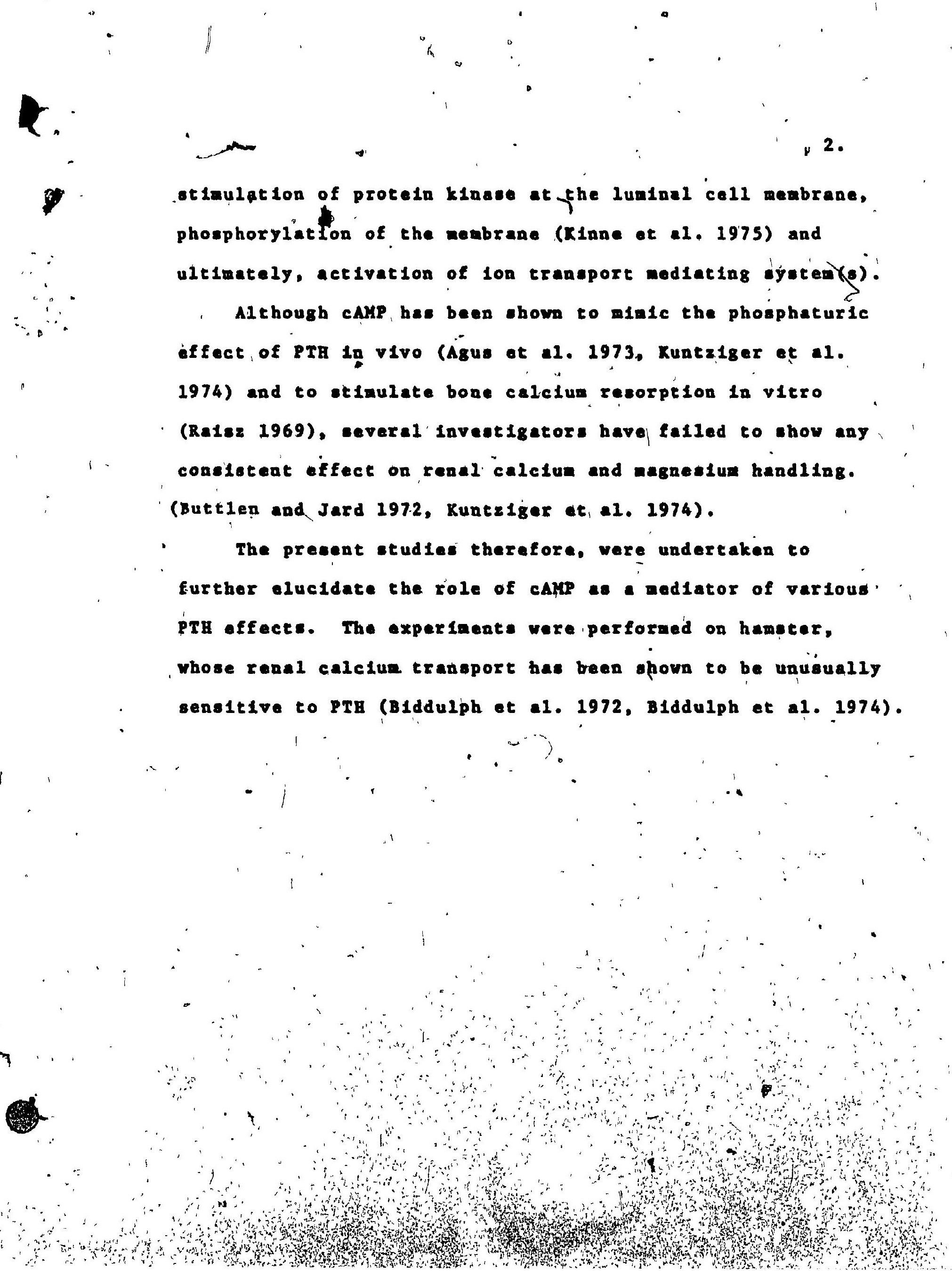


CHAPTER II - HISTORICAL REVIEW OF THE LITERATURE.

A. General Mature of Reial Tubular Tranoport of Phosphate Calciun and Magnestum.

1. Phoaphate

The kidney plays key role in the homeostetic ragulat1on of Inorganic phoephate in body flulde. In general, the viow that phosphace is largely freeis filterid at the" glomerulue of which a portion 18 reaboorbed, and the excese excreted In the urine, egrees well with the experinental evidence. Hoet studies performed at endogenou levelo of plase phö́phite show that phosphate clearance te oubstent1a11y leas than GPR (P1tta 1933, P1tts 1944, Thoigon 1957, Hellmen 1964). thus euggeeting thit excretion is mainly deternined by the procerses of flltration and reabsorption. Dur 1ng:Intrarenoug infusion of phosphete, uriagry phosphace I 1se rapidy to the point whete exch increnerit In the fil-

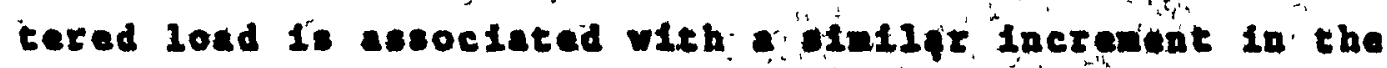
urinary excretion, Indicating attefingent at in uppex linit of net tubular phosphate réaborption; 1.e. a tranoport

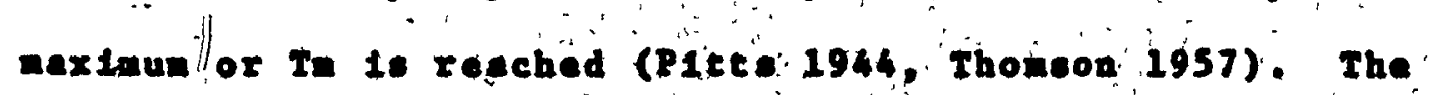

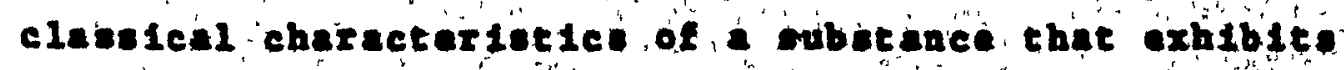

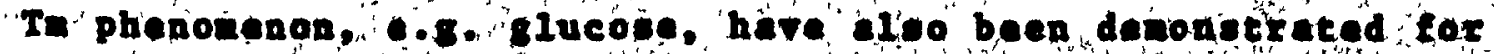

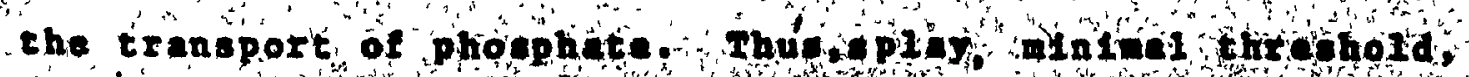

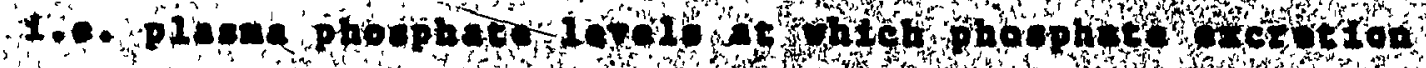


Elrse occura, mexien threbold, 1.e. plabe levele at

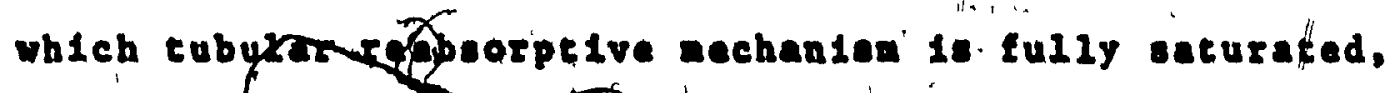

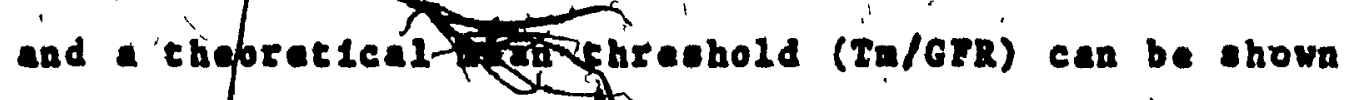
during: phosphate 10ading fotudies. The Tr/GRR is often coneldered a a more ueful expreasion of experinental copditione in nang studies, as it takes into consideration variations 'In GRR previousiy shown to directly affect the Te phosphate (B1froet ot al. 1969). Unl1ke glucose howiver, which under normal conditions is over excreted In the urine, at its In is set very high, the reabsorptive capacity for phoophate is oet et ouch a value, that a Ilght increase or decrease in plagna phosphate concantration results in a change la the rate of excret1ot (Thomeon et a1. 1957). . A100, unilke 8lucose, phosphate reabisorptive capactey to variable and under the influence of body, tores of lone and everal' hornonal factors. stted of Phoiphate Tranoport:

The vitrafilterability of phoppate te the slorieruidu

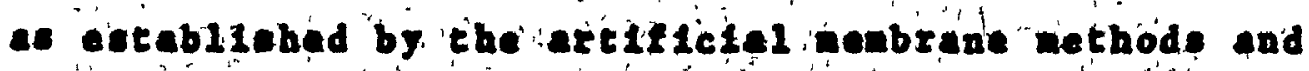

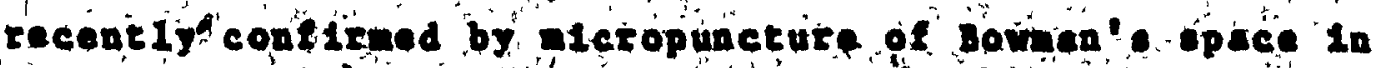

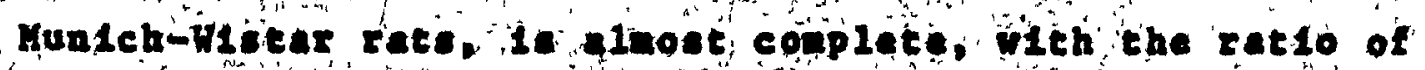

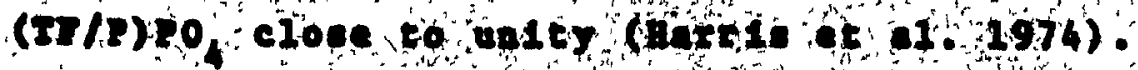


Barly Investigetions suggented that the proximal tubule was slaost ent1rely responsible for phosphete reabeorption (PItts 1933, Strickler 1964). Introduction of nore sophisticeted wethods unmesked the exietence of a distal mechanien of phosphate reabeorption (Antel 1970, Beck 1973, Raox s Lechene 1975). ([t becane apparent froa these studies, that a significant portion of phosphate can be reabsorbed distally, and can equal about 30-40\% of the filtered load. The amount of phosphate reabsorbed d1atelly appears to depend on lts delivery from the proxianal tubule(An1el 1970\%. Vartability in the Intrinalc capacity for phosphete reabsorption along the proximal segment, normally responsibio for $60 \%$ to $70 \%$ af the filtered load, has been reported by alcro-porfusion find tracer injection studiegs ${ }^{32}$ p alcrolnjectión shoved maximun phoaphate reabsorption to occur in the first thitd of the proxinal tubule (staun et al, 1972). Greater reabeorptio, of phosphate in thelfiret portion of the proxian tubuie was ilso reported by Brunete (1973). Thud, In normal abbjecte, about 30 \% of the f1ltered phoophate leave the protinal tubule, and 10-25\% of it can be reaberbed dtetelly in the

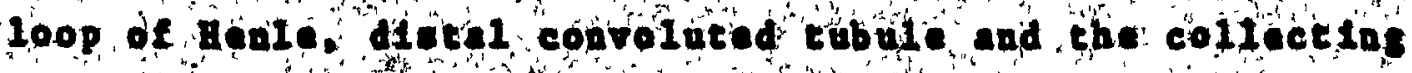

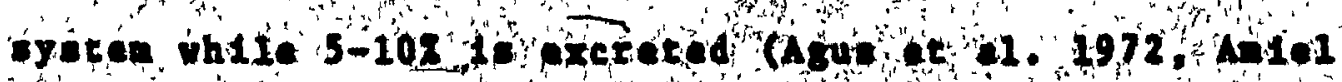
et 1969). 
Poselble Tubular Secretion of Phoophata.

Whether tubuler secretion of phosphate exiets or playe a role in the mechania of phoephate excretion in mammals is st111 a subject of controversy. Secretion of phosphate heo been dlearly demonetrated In áphibia (Walker Hudson. 1937), agloberular f1oh (Marahall ot al, 1933), glonerulax fioh (Wolbach at al. 1970) and the chicken (Levinaky at al. 1957). The evidence that has been Interpreted as Indicative of phosphate secretion by a manalian kldney however denands cereful appraical. Phöephite ectation by the dog k1duey has been reported by Barclay, et ai. (1949) and carracquer et al. (1960). Thene etudies are not concIusive howerer, ince Inlià reaulte of other workers have been Interpreted as evidence againtt aecretion in several polnte that excedded the unity clearance, rat 10 were coneldered to be within the range of ixperinental ertör esociated itth clayrance feterination (P1tit 1933): Attenpte to chö phosphice cecretsob in hunain also sove in-

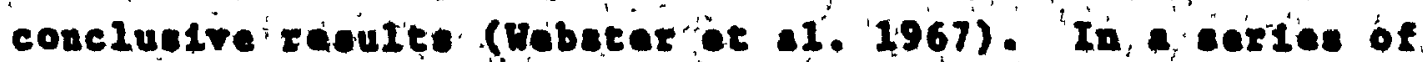

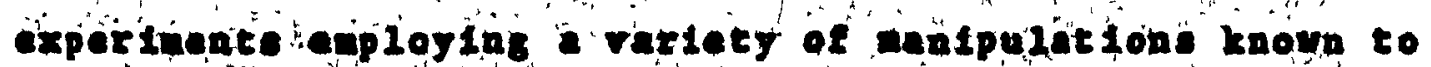

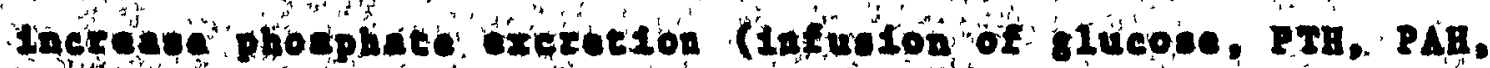

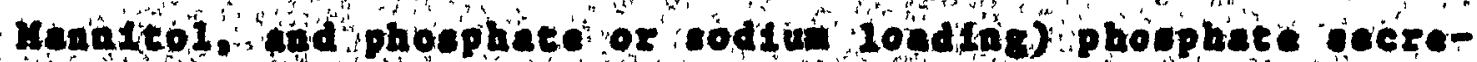

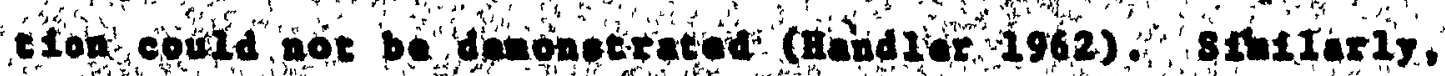

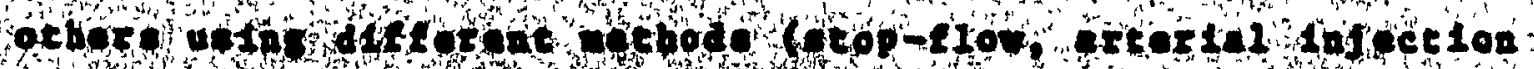


of labelled phosphate, incropuncture) were also unable to denonstrate the presence of aceretory aechaniam in the renal transport of phosphate in elther the proximal or the distal agment (Saniy ét al. 1965, strickler et al. 196\%, Anfel et al. 1970, Agus at al. 1973). Thus, In contrast to fiah, amphibia, and bitds, In which phosphate eecration has been clearly demonetrated, no conclusive demonetration has been reported In manais, and although secretion realns a distinct possib111ty, accunulating evidence suggest: phosphate excretion) to be the result of a balance between its filtration and reabsorption.

\section{Calclum.}

The handling of calciun by the kidney has been a aubject of considerable Investigation. Under normal, noudiuretic conditions, alcropuncture otudies indicate caleium reabsorption to occur throughout the nephron, paralleling that of codiun (Lasiter et al. 1963, Bdwards et ol. 1971, Murayana et a1. 1972). In order to study the renal handiling of calclun however, sone deserenent of lta filterability at the gloinerulue hae to be made. In plabes, calciun exist, In chrea forine, ace aree 10n, bound to protein, and conplexed with raxions anions. Only the calciurin the lonje form Is important physiologicaliy and whereas both frae and 
comp 3 axed are freely filterable. L1ke phosphate. Ca concentration in the glomerular filcrate has been approxinated by artificial wembrane filtration nethods, and recently confirmed by alcropuncture Geudies. Meseured Ca concentration In fluld obtalned from Bownan's spece gave values equal to approxinately $63 \%$ of plasma values which agrede wa11 with the generally accepted value of 607 uitrafilterabllity (Harr1: et al. 1974).

Pasatve reabsorption of Ca in the proximal tubule, as reflected by tubular, fluld to ultrafiltrate ratio (TE/UF) Ca of about 1.0 established in the first portion of the tubule, accounts for 50 to $55 \pi$ of the filtered load of calc1un (Lassiter et a1. 1963, Edwards et a1. 1974, de Rouffigine et al. 1973). Traneport of calclum beyond the proxinel segment is an active process against high concen-. tratioñ gradients. Dletal tubule (TF/UF) Ca rat1os of 0.3 to 0.5 have been reported by several inveetigators (Edwards et 41.1973, dè Kouff18nac et a1. 1973, Agre et a1. 1975, Le Grinellec 1973)." Deternination of quantitative distribution of calciua -reabsorption along the distal aephron dhowed the loop of Henle to be responeible for the reabsorp人tion of 20 , to 30x of the filtered load of calciup, the die tal convoluted tubule for 10 to 15\%, ind collectlag duct for 5 to $8 \pi . ;$ 
existence of an active traneport mechanisa in the loop of $10 . \ldots$ Henle or enrly distal eegment. Litcle importance could be atcached to its transport In the collecting duct (Wen'et al. 1970).

In rodents, however, late proximal tubule (TR/UF), Mg reaches a value of about 2.0 . In these apecies the proxinal tubule thus, accounts for the reabsorption of only 257 of the flltered load of nagnesiun. The loop of Henle appears to be a maln site of Mg transport since as nuch as 607 of the flltered Mg can be absorbed in this segment. Oñly a onall portion ls handled by the distal convoluted tubule and the collecting duct (Nurayana et al. 1972). Thus, at present, the loop of Heple appears to be a matn ate of nagaesium hand11ng in all species studled and the difference in the proxian transport of M8 in dogs and rodents remains to be solved:

In for Kagnesiun.

Suggestive evidence for the existence of linit $\mathcal{d}_{\text {d.cap- }}$ acity of angnesiun reabsorption has been presented and In asgesiun was shown to exhiblt cheracteristics of In phosphate (Measy at al. 1969). 
Possible secretion of Magiesiur.

The posalbility of net tubular secretion of nagnesium has also been suggested. The evidence favouring secretion comes from atudies of Aver111 and Heaton (1960), who could consiscentiy show clearance of magnesium to exceed its filcered loads In rate, whose plasma nagnesiun levels vere ralsed well above normal. Others, however, In similarly magneslum loaded dogs,were unable to show secretion (Saing et al. 1960, Murdough 1960, Massry 1969). M1croperfusion studies in the rat g with intracapillary microinjection of magnesium, also failed to support exlstence of a secretory mechan1sm. (Brunette et al. 1971). Strong evidence againit secretion cones from studies in chickeng, where infusion of magnesium into one renal portal gystem failed to unask trangport of magnealun from the peritubular capillarles Into the lumen (Robinson 1962). Thuis, at present the evidence in favour of magnesium secretion 18 equivocal and in need of further elucidation.

B. Factors influencing the Renal Transport of Divalent Blectrolytes.

The renal cubular handling of the divelent electrolytes $\mathrm{Cs}, \mathrm{Mg}, \mathrm{PO}_{4}$ te under the Influence of body stores and sereral hormonal and nonhormonal factors. Accumulating evidence 
suggests that stmult that influence distal transport oysten are the nost inportant in the regulation of divalent electrolyte franbort, and their final output in the urine. r Seteral formones havk been shopn to have adirect effect on nephron trapsport systems. Administration of either parathyro1d hormone or vitamin D and its matabolites, onhances calcium resbaorption (Talnage et al, 1954, Puschett et al. 1972) whtle calcitonin and growth hormone have the opposite effect (Kenny et. al. 1965, Ikkos et al. 1959). Whereas PTH and calcitonin have been shown to be phosphacuric In nature, (Greenwald et al. 1925, Kenny et al. 1965) ava11able evidence uggest that vitanin $D$ and growth hornone have a phosphate retaining effect (Puschettet al. 1972, Ikkos et al. 1959). Adrenal cortical hormones appear not to have - direct effget on elther calclum or phosphate transport, and thode observed seen to be secondary to extracellular fluid volue expaneion.

of the varlous hornones aentloned however, the one that 1. nost clearly Inportent in the regulation of renal excretion of phosphate and calciun is parathrold hormone. A potantially Important role axiots for vitanin $D$ and growth hormone, but Information is Insufficient to varrant any con-, clusions regarding these agents. 


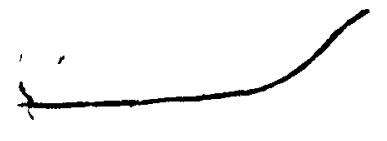

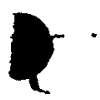

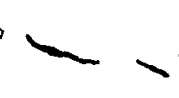

1. Ro e parathyrold Hormone

13.

1. Chentsexy

The eariy recognition of the role of the parathyroid glinds in calcium and phosphate homefotasis led to intenIre Investigation into methods af extraction, purification and chemistry, of the hormone. 34 years elapsed however, between the faolation of the flrat blologically potent extract from pafáthyrold glands by Coll1p (1925) and the preparation of highly purifled hormone by Aurbach (1959). It took another decade before the composition of parathormone becam apparent. The amino acid composition of human, bovine and porcine PTH is very similar, comprising 84 residues with a total molecular weight of 9,500 (Brewer et al. 1972, Aurbach et al. 1972). The blological activity of the hormone resides in the Initial 30 residues of the anino terminal (Keutmann et al. 1972) and synthetic peptides conprising the first 34 anino acide are blologically active. (Potts 1971). PTH 1s synthetised as a prohormone (propTH) of 109 anino acids and molecular we1ght of about 12,000 (Habener et a1.1972), which has to undergo at least one apecific clgavage before, being fully activated. This first cleavage occurs in the parathyro1d cells where proptil 1e converted to the 84 reaIdue peptide (Chu et al. 1973). Th1 fraction, after 
14.

secretion Into the c1rculation undergoes further clear-. age, in the periphery into a, large blologicaliy Inactipe fragment (H.W. 7500), and, ana11 biologically active N tarminal fragment (B1scher'1972). The half $11 f$ of PTH, like mang polypeptide hormones in the circulation 1. relatively short. It has been meacured for both the exogenous and endogenous hormóne and shown tó be about trenty. minutés (Melick et a1. 1965).

\section{1., Synthds1s and desradation}

The syothesis and secretion of PTH is regulated by the extracellular concentration of lonized calcium. (Sherwood et a1. 1968, Ham11tion et al. 1971, 01dhan et al.1971, Tragovnik et a1. 1971, Masery et a1. 1969). Sone evidence for the Involvenent of aagneilua in the regulation of the level. of circulating PTH also exise (Buckle et al. 1968). Nö such refation of PT̈̈ levels to plase-phosphate has been shown (Sherqood et al. 1968), and phosphate regulation of secretion of PTH has been shown to be indirect, via changes In plasma calcium levele.

PTH Is Inactivated. by enxymatic degradation in the kidney and the liver, ance both nephrectony and hepatectony result in a prolonged half-11fe of the hormone (Fang et a. 1972). 
111. Effecte of Parathyrold Hormone on the Renal Handling of Electrolytes.

The Physlologleal Importance of parathyrold hormone In calciui and phosphace netabolis wa esthilshed in the f1rst quarter of this century. The f1rot landark 1n underatanding perathyrold function wae the work of Maccallua and Voegtiln (1909) who observed that ravoral of the parathyrotd glands from doge caused a drop In plasen calclum followed by tetany, which could be temporarily felieved by infusion. of calciun chloride. The second was the success of Collip (1925) who was the first to prepare parathyrotd extracts, to show the rolo of PTH in plaser calclum and bone resorption regulation. Greenwald and Grose (1925) recognited the inportant phosphaturic effect of PIH upon the k1dney. From those observations developed two schools of thought on the mechanisn of PTR action. The Collip and Thompeon school, proposed that the primary effect of PTB was on bone, leading to Its disoolution and subsequent rise in plase calcium' levels. The renal effects were thought to occur econdary to bone resorption (Thompeon and Col11p 1932): The Albr1ght school belleved that PTH ected directiy on the kidney to regulate electrolyte level. In body fluids and that the bone changes were secondary. The observed rise in plasa calcium. was Interpretid as an Indirect affect to keep the product of 
the plasma condentrations of calcium and phorphate lone. conetant. Unfortunately, neither group could present experinental evidence in direct confirmation of their particular theory, and the Initial intenolve interest in the physlology of parathyrold glanda, calciun añd phosphate netabolism abatpd for eeveral raars, owlng apparenty to lack of better hormone preparation and the difficulty in flnd1ng a convenient, cononic agary nethód. Only twenty years. later, as more purified parathyrold extracta became avaliable could these Inftial Interpretations be modified and PTH was shown to have four separate major actionsi

1. Increase in uxinary phoephace excretionfGreenuald 1925 , Pulizan 1960).

2. Decrease in urinary calciun excretion, preceding any change in plasna calclun (Talmage et al: 1954, Kleenan et.a1. 1961).

3. Acceleration of netabolicidestruction of bone (Barnicot 1948; Chang 1951, Ga111ard 1961).

4. Increased calciua absorption from the intertia (ralqabe.

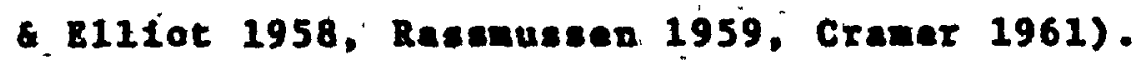

a) Bftect of PTB on Renal Phosphate Transport.

The role of the parathyrotd In renal phosphate netabolian 
has been recosaleed ince the discovery by Greanuld (1925) that parathyroldectony. eaube a rapid fail in the rate of 4rinary phosphate excration and conversely. Injection of parathyrold extract Increase urinary phosphate excrat $10 \mathrm{a}$. Although phosphaturia wa inong the earler detectable responsen to PTH, It was undeclded for several geare whether 1t was due to a drectiefect of the ibspercilcente.

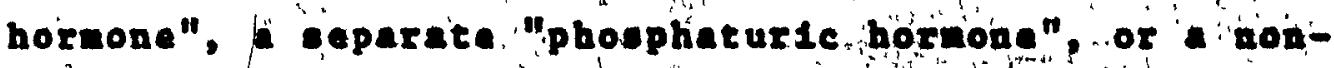
hormonal component of parathyrold extract. Sone cridoned for a separate "phoophaturte fragnent" was predented by stewart and Boven (1952), who shoved thit treatnent of parathyroid extract with formaldehyde abolluhes the hyper:calcéle response, but not the phospheturic one ano ingarate fragnentian 1,0lated however, and" the phosphaturte effect could be reproduced with a highis purified Pra (Aur =

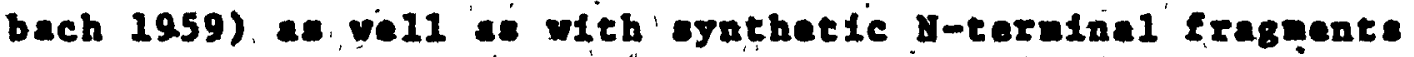
of Pra (Botes 1971):

In the earliex ilecreture conelderebie controversy also axteted, a to whether PTH had ang diréct effece an

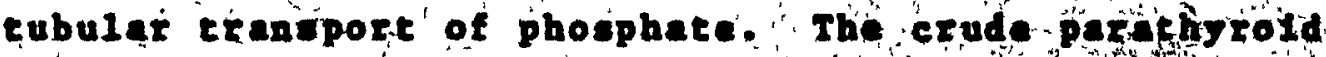

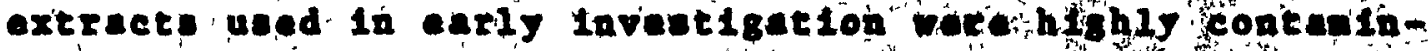

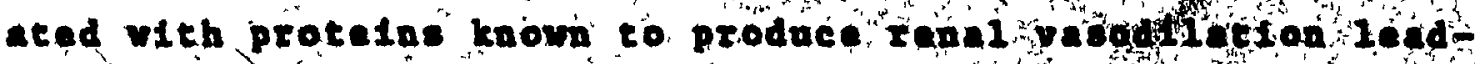

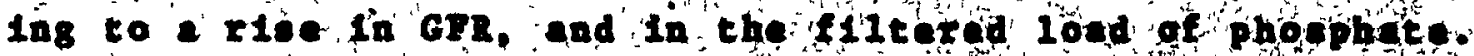

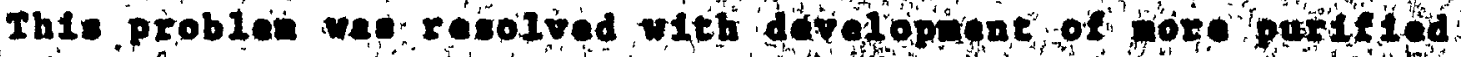


preparations of PTE (Aurbach 1959): The phosphaturte effect of the hormone rad then thown to be indepindent of changes in Gra Indicating direce effect on the renal cubular tranepore of thic phoophate. ITwo nechanisud, of action of parathyrold were tharefore coneldered and Invest 18 at ad:

1. An Increese In tubulex ectetion of phosphate.

2. A decresee in phopphate reabsorption.

The evidence that the phopphaturic effect of PTH is a result of enhanced tubular secretion le concrovereial and Inconcluetve, as the existape of auch a component of phos-

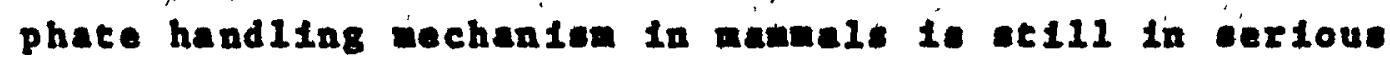
question ( see p. 6). Prosefge gridence favours, lohibition of cubyzer reabsorption of phoshate after PTA, rather than enhanctat' eccetion (Band1ex 1962, Ague 1973, Murarana 1972).

Eridonce of Tubular Reabsorption of Phosphate.

\section{clearance scudies}

The ortginal observatione of Greenwald and Groes (19.25). heve been confirmedind extended over che pret fen decides

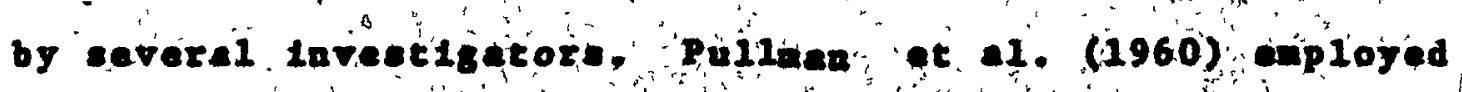

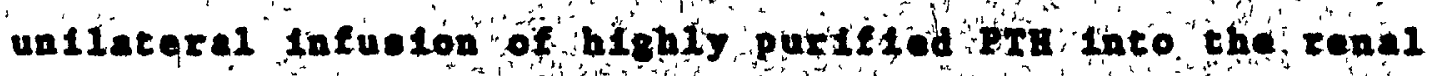

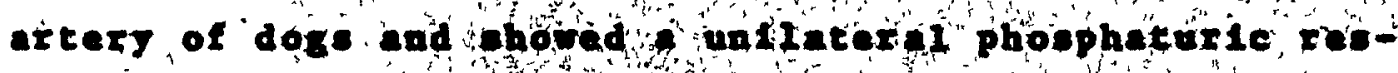

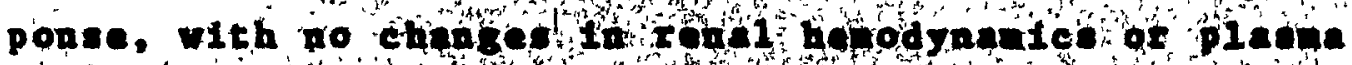

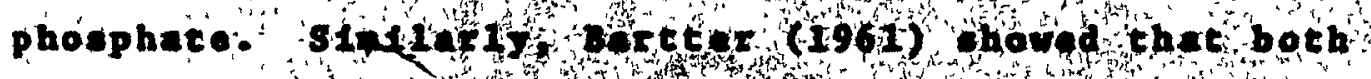

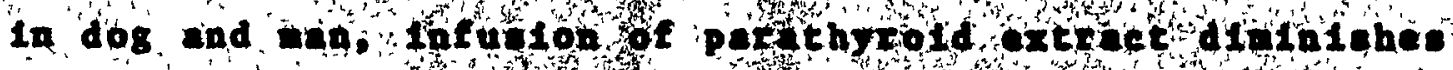




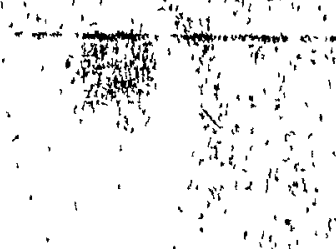

phosphete rebsóption whb no afectobidifereton

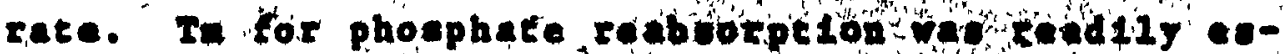

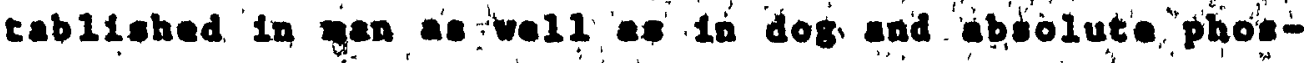

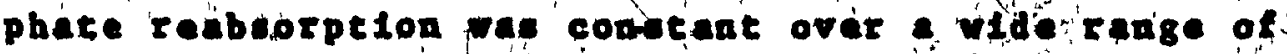

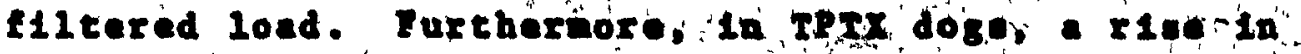

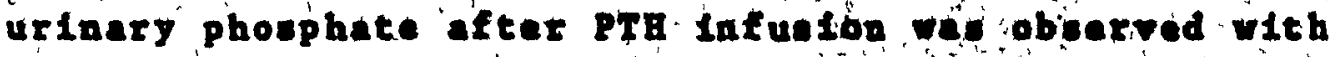
no change in the level of phoephite fliferedg while stop flow study reaule euggested that in the abjofice of PTH nost af tho rebuozption occurred proxinalis

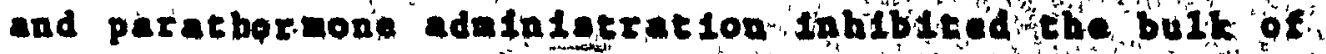
th1s proximal phoophate reabeorption (soity el ig65). Micropuncture studies - Stre(a) of "PTH action

Introduction of meropuncture technigues faciliteted the etudy of electrolyte handising long thetubule. It

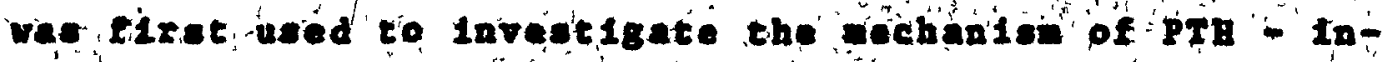

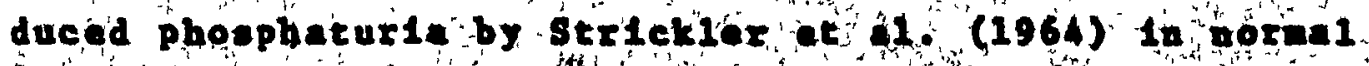

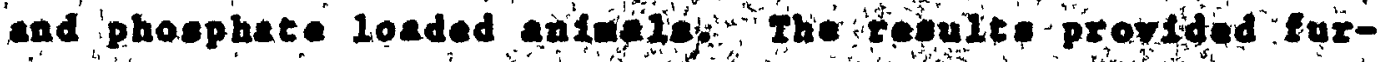

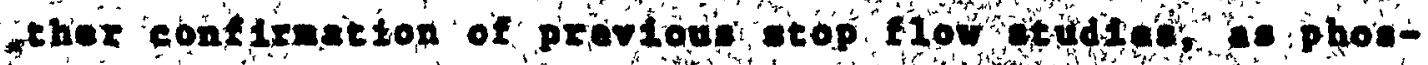

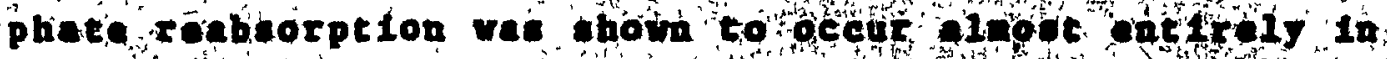

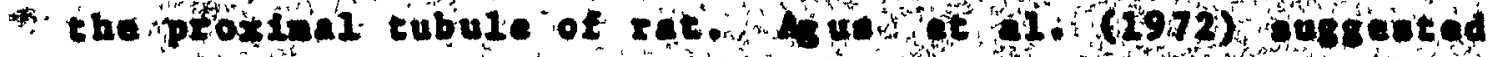

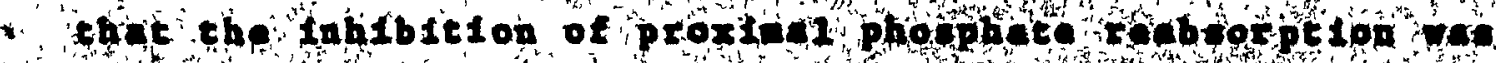

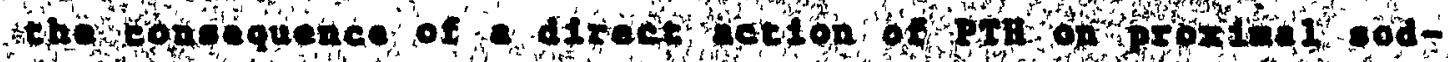

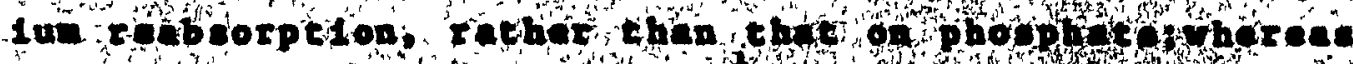


purtuary codium excretión wag shown to be unchanged; Indecting further distal sodtum reaboorpt1on; phóphate excration was Increased. Howevior, disapciation of the proxidicl aftect of PTB on codiui and phosphate in the dog has been reported by Wen (1974). At present, - it is known that at lesst portion of the proxinel phosphate handling io closely linked to that if He (Agus et ol. 1973).

Distal phosphate reabsorption was ugsested by the rasulte of Wen's study, but the phosphaturic effect of PIH was attributed to the proximal tubule. Clear evidence for Inhlbltion of dietal phosphate reabeorption by PTH cones fron studies of Aniel, Kuntziger and Rlchet (1969) In normal and in beth acukely and chronically TPTX rats. Acute and chronic TPTX animale reabsorb a greatax Fraction of phoophate delivered to the distal tubule in

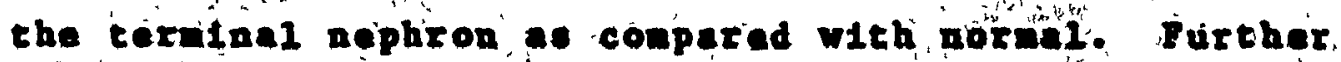

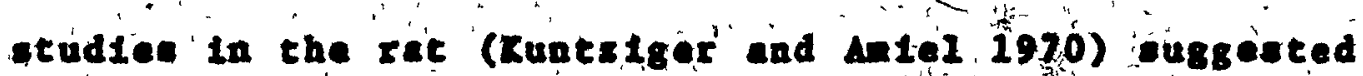
the loop of hienie a another posalbie ilte of the action of ptu. "This Is In "agrentent with the observations of

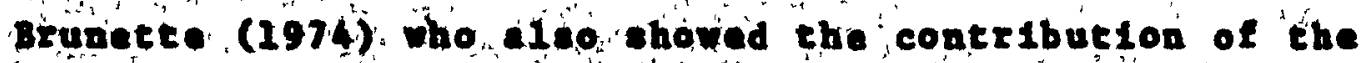

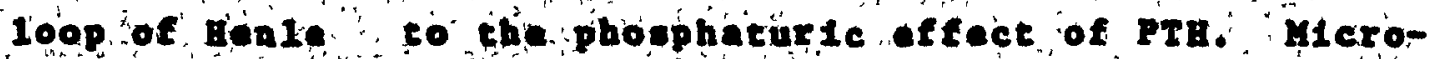

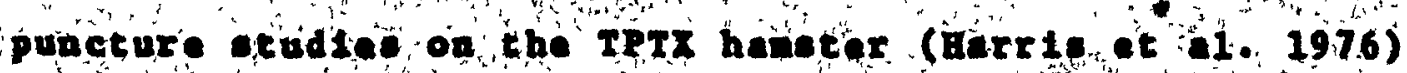


polut not onig to a drop in'the proxinal phosphate re- is abeorption after PIB adula1stration, but also lnethe - loop of Henle and beyond the'dletal tubular puncture 1te, Indiceting an affect within the collecting egetem. The role of the collacting soten in the phosphate handIIng was also noted by Allel (1970). Finally, ecudiea of Inox and Lechere (1975) confirm observatione of others, that In'additian to the proxinal action, Inhibition of distal phospate reabsorption is an important factor In the phosphaturic effect of PTH.

The distal capacity for phosphate reabsorption and Its sensitivity to PTH can be unnesked by saline loading or adninfetration of diuretica. Saline-induced phospheturia has bean etudied, in recent years, and it has been susgested thyt thig is a consequence of PTH release eince asine Infusfon inco TPTX aninals produced no phosphaturia (Fxick et 1. Fo9, Hesery-1969). Heropuncture atudies of volute expapsion lidicate that in presence of pra nost of the phosphate delivered dieta11y' lo excreted (Pubchet et al (972); ifter Tptx, proxinal tubule response to

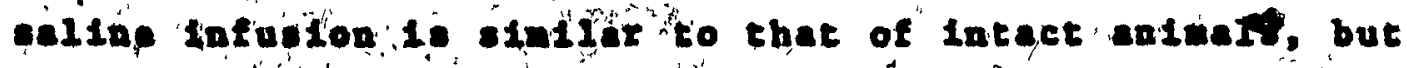

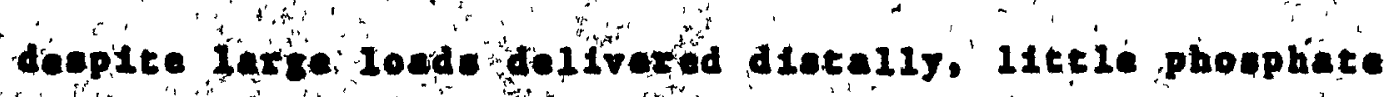
oppeara In the urine (bet 1973, Friek 1969) 
Many diuretice are also phosphaturic in aature, to a varled degree. In general, the most effective are the paes that have carbonic anhydrase Inhlbitory ectivity (Goldberg, et al. 1973). Following 1nfision of Acetazolanide Into Intact animals, proximally rejected phos"phate escapes distal reabsorption; In TPTX aninale an1larly trected, the large phosphate load leaving the proximal tubule 1s reabsorbed distally; and little if any phosphaturia occure (Bock et al, 1973). Thus, these studies reveal the exiatance of high capacity reabsorptive mechanian in the distal tubule for $\mathrm{PO}_{4}{ }^{\circ}$ The combination of distal load and extent of lnhibition by PTB deternines the magnitude of phosphaturla under a varlety of experfmental conditions.

b: The effects of PTH on Renal Calclun Handling

The net effect of PTH on renal calclum handling is rather difficult to predict, since lt is the sun of several forces acting in opposté directions: Its effecto on bone, resorption and Intectinal reabsorption lead, to Increased plasma calclun concentration, and a consequét r1eo In flicered calctum load which may increase urinary calclun excret1on; therefore masing a direct effect on tubuif calciun reabsotption. The evidence for a direct 
effect to enbance tubular calclun reabsorption lo considerab1e. Talaege, Kralntz and Buchanan (1955) demon'strated In rate that TPTX caucea Increased renal calciun excret10n at the same tine lowering plesma calciuniparathyrold extract injection restored both variables to normal. Widrow and Levinaky (1962), howed a drop in calciun excretion during PTH Infueion in dog, deoplte rise or no chenge In flltered load of calcluin. Kleunan and co-workera (1961) mede elmilar observations in man, showing that PTH opeciflcally, decreased renal calclup clearance. E1senberg (1965) gave PTH to hypoparathyro1d patlents continuously infused with dalcium and shored the hypocalcluric effects to be independent of changes in plasma calciua. ' sinilar observations of high calciun clearance. relative to plasma calclua in hypoparathyroldian have been reported by othere both In ana and laboratory antmelo (Nord1a Peacock 1969, Bíddulph et al. 1970). Also, 10w calclum clearance relative to plasma calclum levelo has been shown in hyperparathjrold patients. (Mord1a et al. $1969)$.

sices of the Action of PTH on Renal Calciun Traneport Along the Keptron

The ste at which parathyrold hormone enhances calclun reabsorption has not ret beẹn clearly 1dentified. The previougly inestoned Sedp-flow atudy of H1drow and Levingky 
In the dog, suggested the distal segaent of nephron as a poesble ste of this effect. Mlcropuncture and microperfueion atcenpti have been made to further elucidate localieation of PTH effocts on tubular calclum tranaport. Brick et al. (1965) shoved proximal reabsorption of calcium was unaffected by RTH, e48gesting a nore distal - Ite of action. Micropuncture ctudies In the dog deaonstrated that PTH ectualiy has a dual effect on calciun tranepore: in the proxinal tubule absolute and fractional reabsorption of calcium and codiun were Inhiblted;urinary

- calcium excretion was reduced despite increased sodium excretion Indicating a disproportionate enhancenent of calciun reabsorption in the distal nephron (Agus et al. 1973).

The above observations of a selective enhancenent of calciun reabsorption at a dietal atte, are, in agreement with those recently reported by Sutcon et al.(1976). They showed that PTa lincreaces refection of fodium and calciun proportionately in the late proxinal cubule in both Intact and TPTX doga. Increased deltyery of both lons to the distal tubule after PTB adelniatration was therefore observed. However, the ratlo of fractional excretion of Ca to Va decreased, suggeering belective enhancenent of cafclun reabeorption before the euperficlal dietal puncture 
8te. Purther drop In Ca/Na ratio in the final urine Ia both groups polnte to' a Inilar action of PTH on calclur reabsorption beyond the accesablediatal convoluted tubule. Recent nicropuncturé studies in the hameter, whose renal calciun cransport is highly ensitive to PTH strongly supports these observationp; as PTH effects to enhance calciug reabsorption could be locallsed both to the ascending linb of the loop of Henle and to the terminal nephron segnent, (Harris at al. 1976).

Thus, preclse localisation of the effect of PTH on renal calciun transport remalne uncertaln. Present evIdence points to the loop of Henle and wore distal segments Inaccesible to nicropuncture as the sites of hormone action. c. The effecte of PTB on Renal Magnesiun Hand11ng The effect of PTH on the renal transport of nagnesiun 1. even less well defined than 1ts effects on calcium or phosphate. Experinental evidence for the relation between calclum and magnesium netabolium dates back to the work of Mendel and Benedict in 1909. The recognition of the role of PTH In calciun hemeostas, led to early Investigations Into PTE effects on plasea nagnesiun.. Although a rise in plasa agnesium in doga 
Injected with parathyrold extract was reported by Greenberg Mackay (1932), no effect of PTH on plasma Mg could be seen 1n, hyperparathyrold18m (Bulger Gauamana 1933). The absequent studies vere as equivocal as the earlier ones. Desplte a drop in plasma Mg after PTX in dogs an Increase rather than a drop in urinary magnesium was observed after PTH adninistration (Heaton 1960). However, PTX In rats (MacIntyre et al: 1963) led to a drop in plasma Mg as wellas.a fall in Mg and $C$ a excretion during PTH adaniatration. Calcium retention correlated well with the dose of PTH. Experimental magnesium deficiency led to " hypercalcenia, hypophosphatemia and a rise in urinary phosphate. This controversy as to the effects of PTH on urInary magnestun was later resolved by Coburn and Massiy (1969): Investigation of the effects of calcium infusion on renal handling of magnesiue with normal and reduced GFR, showd that calciun Infusion caused a rise in urinary magnesium even if filtered load of magnesiun dropped, concluding that they share common pathways for reabsorption. This otudy would also explain Heaton's results, since' the animals he used were hypercalcenic. In later gtudies Massry and co-workers (1970) have shown that the effect of PTH on renal aegnesiun transport is Independent from that of calciun, and that PTE causes a decrease in the fractional 


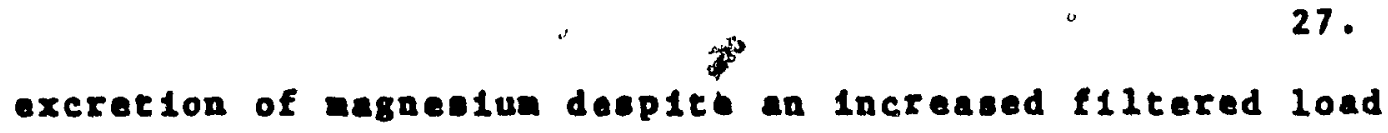
thue confirning flndings of Macintyre et al. In hypoparachyrold patienta drop In urinary agnesiup assoclated witb a drop in urinary calciun after intranuscular PTH Infection vae obeerved (Bethune 1968).

L1ttle, if any, "evidence for the precise localieation of PTH enhancenent of aggnesiun reabẹption in the nephron exista. Micropuncture atudies of Brunette (1969) point to the loop of lenle as a poselble site, while the evidence from Harris et al. (1976) study in tha hameter polnts. to both loop of Henle and the terminal nephron as the sites of PTH action on the transport of magnesium. Thus although the effect of parathyrold hormone on renal magnesiun handling in varlous gegments of the nephron seems to parallel that on calcium, the evidence is equirocal and awalts further Investigation.

2. The Role of caMp in the Mechanise of Action of PTH on the Renal Transport of Electrolyter.

It 1 s currentig felt that any hornones act by way of a double fesenger ejoten. Hormones are regarded as a first masenger which travel from their celle of orIgIn to the cella of target, tiseue where they then stinylate formation of a second messenger. At present, the only second meseenger identifled is cAMP (Sutherland 
\& Rahl 1958), and it implication in the action of many peptide hormones, endocrine and exocrine secretion, as well as neurotransenter relesse, strongly favours the proposed Eechan1sa (Rob1nson Butcher 1962).

An Increasing body of evidence supports the hypothesis that caMp 1, also a key mediator in the action of PTH, and that this action of the hormone on the kidney depends upon the following sequence of events; interaction of the hormone with specific receptors on the cell surface of the renal tubular epitheliua - activation of adenyl-cyclase as the result of the Interaction with receptors: generation of latraceilular cAKP;activation of protefn kinase within the brush border of renal cells: phosphorylationi of an enzyge(s) or a momane conponent: and, as a conequence, actiration of a ojaten mediating transport of lons.

1 cakp gineration in the Kidney

Changes in the urinary levelo of cAMp can be regarded a a phyalological consequence of direct activation of the above syetca.' Presence of cAMP in urine vag flret demonstrated In human's (Butcher sutherland 1962), but no

i. physlological Importance wa then attached to 1t. Chase

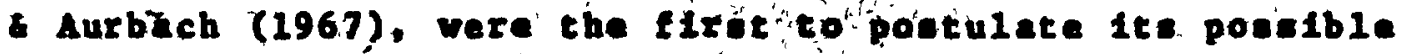


role In mediating the action of parathyrold hormone. They showed that urinary caMp levels were lower in the TPTX animals as compared to the intact. Intravenous injection of PTH Into TPTX rats Induced an Imnedlate and marked riae in urinary cAMP, which eltherpreceded. or colncided with the phosphaturic effect of the hormone. -Similar changes in the CAMP. levelo In the urine after PTH administration have been reported In humans (Kaminsky ets a1. 1970).

These effects on the urinary cAMP levels reflect cyclic nucleotide elaborated from the renal cells in reaponse to the hormone and not a rise In Its clearance from plasme. In the study of Kaminsky et al: (1970) it was possible to segregate cAMP, appearing in the uriné according to nephrogenous or systenic or 1g1n. Oniy the nephrogenous, part was under the control of PTH. Chase Aurbach (1967) and Buttlen and Jard (1972) using rad10active CAMP also showed that the rise in the renal output of the nucleotide after PTH reflected renal oynthesis excretton, and was not a result of a rise' ln its clearance. Purthermore, an increase in the intraceliular concentration of the nucleotide in the kidney cells has beep detected

* after Injection of the hormone in vifo (Rasmuseen t Tenenhougé 1968), after add1tion of the hormone to 1molated 
renal tubules (Aurbach 1972) or to 1801ated incact cell preparations'fron the renal cortex (Kelson 1970).

The 1mportance of cAMP fs further otrengthened by the findings In patients with pseudohypoparathyroidisn, a condition representing an end orgen unresponsiveness co PTH despite' normal, or elevated levels of circulating PTH, In these patients, a lack of phosphaturia after PTH adainistration 1o paralled by a leck of rise in the cakp levelo in the urine (Chase 1972).

11. Hornone Receptors in the Kidney

Since many other hormones also'alter the metaboliam of cAMP, the question of specificity arises, and considerable Importance' has been attached to the anatonical localleation of these effecta. Specific receptors for parathyrold horwone have been Identifled in the renal cortex by sutcl/ffe et al. (1973) using $125 \mathrm{I}$ labeled-PTH and by D1Bella et al.(1974). B1010g1cally Inactive PTH, as we11 as other' hormones such as yasopresin, glucagon and eplnephrine failed to lahibit binding of the active hormone.

\section{Adenyl Cyclase.}

The binding of the hornones to mentane receptare" is: a process closeig linked to but eparable from, activation 
of adenyl-cyclase In the receptor tigue for these hormones. Accumulating evidence suggents that although Interaction of many polypeptide anine hornones leadg to the activatton of this syoten and oubsequent riob fn the intracellular cakp production, the receptor for these horwones are highly ipecific and probably located on distinct cell types (Heath Aurbach, 1974). PTH selnulates adenyl-cyclese predoninanty in the renal cortex (Ohase et al. 1970), and recently it has been hown to be preferentially diatributed In the contraluminal plasma neabrane of the corteal epithel1al cello (Shlatz et al. 1975). Furthermore, PTB ensitive adengl-cjclase hat been identiffed In the proxImal tubule, pars recta, thick ascending linb of Henle, dietal convoluted tubule, and cortical collecting duct (firat branching porition). '(Chabardes et al. 1975). With' the exception of the paxi recta, these are also the known sites of PTH Induced alterationa in the transport of electroIyter.

Vacopressin, another bormone whose iffects are nedlated by cAYP, gtinulatpip adenyl-cyclase of renai nedula on19, (Chase et al. 1970), Io keepies therefore itth ite effect on che pernedility to water in the coliecting

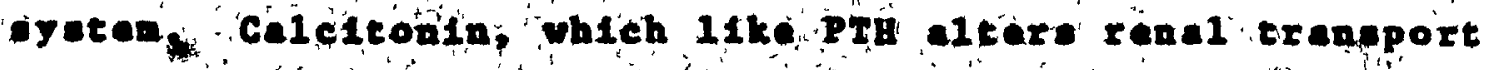

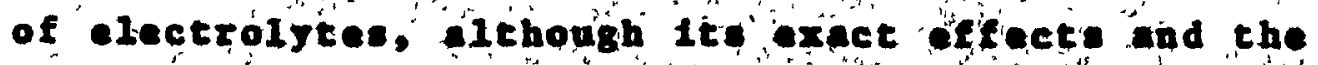


mechantan of action are it 111 rather "poorly defined, 18 also belleved to ace via the adenyl-cyclese cAMP eyjetan. Ite effect howerer has been hown to be epecific and distinct from that of PTB, alnce when the hormones were adninletered togecher, an additive effect ves obsarvad (Heersche at al. 1974). Other hormones whlch ragulate functlons by activating adenyl-cyclase of thelr target t1seues (e.8. corticottapln and glucagon acting on the adrenal and liver reapectvely) were not found to bihd to the PTH-specific receptors of the renal tiseue (Sutcliffe et al. 1973), of to Influence uitinary levele of CAMP (Chase Aurbach 1967).

IV. Protein Kinaser

several studies support the hypotheals that in cella reeponding to hornones through the activation of adenylcyclase and: redialtion of camp, cyclic nucleotides cause activation of protein kinases. (Marx at el. 1973). The renal tseve etudies showed that it is the ectivation of the brush border protein kinase by the eleveted intracellular concentration of caMp that ia reaponedble for the preferential phosphorgletion of the ludinel anbrane-

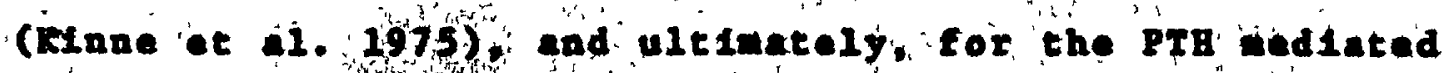

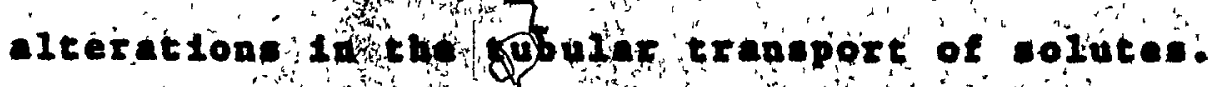


v. Involvenent of cAHP in Ion Transpore

To further etrengthan the hypothesis of CAKP Involvenant in the action of PTH, in vitro and in vivo etudies Involving the nucleotide were perforned, In an ettempt to reproduce the known effecte of PTH.

a. In vitro studies

It has been 'shown that exogenous cAMP dóes not alwayg alnic the effect of PTH; poselbly because nost celle are relatively Imperaeable tol phoophorglated conpounds In general, and cAMP is also aubject to tapid hydrolysis by phosphodiesterase into the laiert 5'AMP metabolite. Butyrated derivatives have often been used to replace CAMP as they have been shovin to have higher cell membrane permeablifty as compared to the parent nucleotide. DBcAMP was sown to be wuch more potent than cAMP In the Intact IIver cella but not In cell extracts (Posternak et al. 1962). Furthernore, Hershe et al. (1971) howed DBcAMP to be nore phosphodiesterase realstant, while the results of Aurbach et a1. (1972) suggest it acts as an Inhibitor of the phosphodlesterses, causing thereby en eccunulat $10 n$ of endogenous cAMP!

The concentration of axogenousiy adinistered nuce1ot1de aloo eppears to be of "yttal inportance. Dose reoponse. 
ctudies with DBCAMP, In the lntact cills of different elesuei (adipose; Ifyex; bone) sare a bell shaped curve orér a relatively narrow concentration range (Vaea èt 1. 1969). S1milarly,Rales ot al. (1969) showed that whereas PTu had a arked effect on bone resorpt100, no such affect could be ibown with caMp in dosec up to $3 \times 10^{-3} \mathrm{M}$. DBchMP however, ettmulated resorption at doses of $5 \times 10^{-5} M$ to $7 \times 10^{-4} M$, the reaponse being elailar tó thet obtained with the low doses of PTH." At concentratione above $10^{-3} \mathrm{~K}$ the effect was. lodt.

Thua, elthough DBCAMP appears to be nore potent than caMp 1teelf, the question as to whether the biological effect of DBcAMP is due to augentation of intracellular concentration of cAMP, or to a direct action on the protein kinase remains to be answered.

b. In vivo studies

Effects of cakP on the transport of 'phosphate'

The physlological effecto of cyclic nucleotldes yere also 1nvest1gated. The phosphaturic action of PTH on the

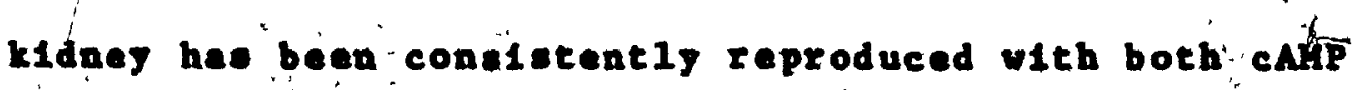

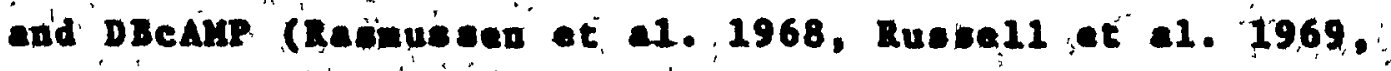
dgue et a. 1971, Kunts18er et'al. 1974). In doge, atther eysegic or renat artery infunion of dicamp lad.to - Ifie in urinary phosphate exeretion tind1cating dirget 
tubular, effect. Replacenent of the active nucleotide with 5'cAKP, 1t: Inert netabolite, falled to inhibit phosphate reabsorption, Furthermore, mictopuncture resulte iggested that the proximal tubule was a predominant ite of the PTH-11ke effects of DBCAMP; drop In phosphate reabsorption was accoimpanted by a drop in reabsorption of Na; thus supporting the view that phosphaturia resulted fron the-inhibition of próximal Na reabeorption (Águs et al. 1971). A ein11ar Inhibition of proximal tubule fluid reabsorption by DBCAMP has aso been observed In Isolated perfused proximal tubule (Hamburger et al. 1974). Studies in TPTX rats revealed the existence of cAMP sensitive $\mathrm{PO}_{4}$ transport beyond the proximal tubule (Kunteiger et al. 1974). The effects/ of caMp were localized to the teranal nephron. These are the sane sites as those thought to be Involved in the effect of PTH on the transport of phosphate, and localleation of PTH sensttive adenylcyclase (Chabardes et al': 1975).

Effects of caMp on the Transport of Calcium There is 11ttie evidence that the affect of PIB on Ca clearance by the kidney al ao lavolve mediation by CAMP. Raguseen et al. (1969) reported that changes In urinery calciur and phospate during cAMP infusion were 
1dentical to thoee during adninietration of PTH. These were $10 n g$ cern experinente howevar, and a riee, rather than a drop in urinary calciun was obeerved with both cAMP and PTH, while PTI and cAMP had an opposite effect on magnesiun excretion. An inhibitory effect of DBcAMP on proxinal calciun reabsorption sinilar to that of PTH was reported (Agus at al. 1972), but uplike PTH treated aninals, where hypocalcuria was observed, no change in urinary calciun excretion was present in graup infused with DBCAMP. Kuntziger in atudy where he clearly denonstrated an effect of cAMP on the trasepoit of phosphate along the nephron, falled to show any effect of the nucleotide on the transport of elther calcium or magnesium. Plagna levelo of these electrolytes vere also unaffected. The hypercalcenlc response to both nucleot1des was Investgated (We11s' and Lloyd 1969), acutely and chronically in TPTX rats. Whereas DBcamp caused a r1se In plasea calciun and a drop in phosphate sinllar to that shown with PTH, neither effect could belohown with cAHP. Dowever, theophylline, a knowh cyclic nucleotide phosphodiesterase Inhibitor, which causes a rise In the Intracellular cAMP concentration produced a asnpifleant increase in cerun calciun, and when added with DBcaki the effect, was aditive. On the contrary, 
In1dasole, a potant activator of phosphodiesterase, ant- , agonleed the hypercalcuric action of DBCAMP as well as PTH. A doserresponse etudy showed the hypercalcanic effect of DBCAkP to be dose dependeńt, an observation almilar to. that of the In vitro atudies of Risis discusaed previously, thus further emphasising, the importance of the dose, when Investigating effects of the nucleotides.

In sumnary, these observatione, although ln etrong support of the Involveinent of cAMP in the phosphaturic effect of PTH, are Inconclusive with reapect to their role, in aediating the action of PTH on the repal trangport of calcium and magnesium.

Chapter III - GOLDEN STRIAN BAMSTER (MESOCRICETU'S AURATUS) A MODEL FOR THE INVBSTIGATION OF THE MECHANISM OF PTH ACTION OA THE KIDAEY

-

As discussed previously, the evidence, that PTH regulates calcium clearance by the kidney la overwhelming. However, the exact aechanian of this eftect is not known. In designing experimenta to further complement ather fragmentary knowledge regarding the equence of the cellular events lavolved In this action. of the parathyrold hormone, the golden haveter appeara to be an Ideal model, 
as 1ts ronal calciun transport has been shown to be unusually sonstelve to PTH (BIddulph at al. 1970, 1973). In the course of their Investigation the hainster kidney was obearvad to play a dominant role In, the anked and rapld lchanges that occur in serum calciun concentration after IPTX or exogenous PTH. A drop In plasma calciue with a conconitant riep In urinery, celctue after acute TPTX could be prevented by either infusion of PTR or nephrectony, whereas nephrectony alone had no effect on plasma calclun levels. (B1ddulph et al. 1970).

Dose-response characteristics of urinary calciun levels In response tó exogenous PTE were also studied to determine renal sensitivity to PTH. A linear drop in urinary calcium accompanted by a rise ln plasma calciua was observed over a dose range of 0.8 to 10 units of PTE. The latter dose was the minimun dosage required to restore calclua excretion levels to those observed in the Intact anials. The urinary levels of calcium fn the hamater were shown to be highly Influenced by levele of dietary calcium as plasma calcium was maintained constant, further underifing the importance of the kidney in the uinute to minute regulation of plasta calciun (Biddulph et a1. 1973)., A phosphaturtc effect of PTH was sloo seen. Howevaf, unlike in other apecies, where Pru cuuses a 
39.

rapid lall in plasan phosphate, In the hameter, PTH falled to lower levels of serum phosphate. This ay Indicate - difference in the mechanism of the phosphaturic effect of PTH In the two species (BIddulph et al. 1969). Further Investigations are required however, before any canclusion can be drawn.'

Chapter IV - METHODS

1.- Animal Preparation

Standard clearance experiments were performed on 54 male, golden hamsters (Mesocricetus auratus), 90 - 1308 body we1ght, allowed free access to food and water. AnImals were aneshetized intra-peritonealiy (1p) with Inactin (Promonta, Hamburg, Germany) (18, mg/100 g.b.wt.), tracheotoalzed, and volume expended to $5 \pi$ body weight with $0.5 \%$ saline (1P) - Acute thyroparathyroldectony (IPTX) vas performed by cauterisation in all but the intact controls. Polyethylene catheter: (PE50), were Inserted Into a jugular veln for the Infusion of Inulin, and into the carotid artery for blood sapling. Urine was collećted fron a catheter (PE50) Inserted Into the bladder. Antals were kept at constant body temperature $\left(36-37^{\circ} \mathrm{C}\right)$. 


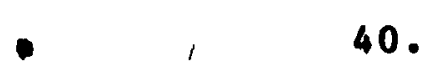

2. Experimental protocol

Aninals were divided into five groupa. The protocol enployed was Ident1cal in al1 TPTX animals (group I-IV), except for a different drug infused in the experimental phase of each group. Group $v$ were the intact controls. Clearance perlods were started at two hours post TPTX and conslated of two 60 minute phases (control and experimental) separated by 60 inute Interval. The cóntrol and experinental phaseseach comprised two 30 minute urine collection periods." Blood samples were taken at the end of each phase.

Throughout the experiments all animalg were infused with 3.57 inulin in 0.97 saline at $0.02 \mathrm{ml} / \mathrm{m}$. The equllibration of Inulin concentration in the extracellular filud compertaent was asaured by infusing it for one hour before conmencenent of the first phase. Group I (the TPTX control group) recelved onlythiglnfusion throughout both phasea. In group II-Iv, adninistration of PTu, cAMP, or DBCAMP respectively was comenced at the conpletion of the firet phase and the experimental clearances were begun one hour later.

Group II (ne 14) recelved purified bovine PTH (W1lson Laboratories Chleago I11.) at 50/hour.

Group III (n - 8) recelved cAMp (s1gna Chenical Conpany, st.Loule, Ho.) $\left(5 \times 10^{-8} \mathrm{H}\right.$ prine followed by $10^{-9} \mathrm{M} / \mathrm{minj}$ 
41.

Group IV $(n=9)$ recelved DBcAMP $\left(5 \times 10^{-8} M\right.$ prime followad by $10^{-9} \mathrm{M}(\mathrm{min})$.

To determine effect of acute TPTX, aroup of e1ght an 1mals with intact parathyrold glands was included in the otudy.

Experiment: with DBCAMP (group IV), In wh1ch a drop in plasma calcium was observed, were repeated on an additional group of four animals that were infused with $1.6 \mathrm{mEq} / 1 \mathrm{CaCl}_{2}$ together with DBcAMP in the exper Imental phase. Th1s low background Infusion of calclum prevented a dxop in plasma calcium and filtered load of calcium.

\section{Cherical Methods}

In 211 experiments, the glomerular filtation rate was measured by Inulin clearance. 100 ul of plasina was deproteinized, with 10 w1 of $25 \%$ trichloroacetic acid prior to analysis for Inulin and phosphate. Plasa lnulin was determined by the fluormetrlc dimedone method of Vurek Pegram (1966) and urine inulin by the anthrone nethod of Fuhr, Raczmarczyk and Kruttgen (1955). Plasma and urine Ca and Mg were deternined by atomic absorption spectrophotometry (Perkin E1mer 303), and phosphate by Chen nethod (1956). Fractional excretions of calctum and ragnesiun were based on mean ultrafilterable values of $60 \%$ and $70 \%$ reapectively. These flgurea were derived from ultrafiltrat1on of pooled TPTX haseters, blood through artiflcial 
42.

membranes. Micro Heriatocrit Reader (Modes L-550 A Phil11ps-Drucker) was used to determine henatocrit levels. Plasma protein was measured with a refractometer (American Optical Company, Series PR -A).

4. Methods of analysis

Significance of the difference between the means in the two phases was obtained by unpaired 'student it Tets. Unpaired, $T$ testa were uedfor comparison of different f groups of animals. Fractional excretion rates were calculatedaccording to the following standard formula:

$$
F E_{x}=\frac{(U / P)_{x}}{(U / P)_{1 n}} \times 100 z
$$


Chapter $\mathbf{V}$ - Rasults

1. Coipariog of 1ntact and TRTX hamaters

The effects of acute TPIX in the hansters are shown

In Table I. Ho signiflcant differencea in GR and urine

flow rate were observed between the two groups of animals.

In TPTX hametera total plapna calctum was. lowex than intact animals, whereas fractional calctum excretion of $2.8 \pm 1.07$ in the intact aninals was arkedly different from that of $11.9 \pm 1.67$ in TPTX hansters (p<0.001): Stmilar differences in magnestum handling were observed between the groups. Total plasma Mg was lower in TPTX than Intact havisers $(.2 .6 \pm 0.1 \mathrm{mg} / \mathrm{vs} 2.4 \pm 0.1 \mathrm{mg}$ $p<0.02)$, while Fug in the intact was higher $(5.4 \pm 1.8$ $v=18.7 \pm 2.57 p \div 0.01)$

The fractional phosphate excretion of $41.6 \pm 6.9 \%$ in the Intact:group ras signiflcant1y different from, that of $2.9 \pm$ $0.97+$ in TPtx hámeters $(p<0.001)$ : However; there wes no - Ignificant difference In the plasa phosphate concentration although it tended to be-higher in thes TPTX 8 roup( $3.2 \pm 0.11$ m8 - 18. the intact va. $\$ 5 \pm 0.7$ igx in (PTX). 
144.

\section{Effects of PTH and cyclic nucleot 1des in TRTX hamstare}

1. Hewodynamic changes (Table II)

Neither PTH, cAMP nor DBCAMP capsed elgnificant daanges In GPR or urine flov rate, but algniflcant fall in hematocrit dad pląsna proteln was observed In all groups, Inc̈luding the control. This was possibly attributable partig to renoval of blood for analyals and partiy to volume expanolon, as the Infusion rate was higher than the urinary output.

11. Charges in calcium handling, (Table III Fig. I)

While' there was nó change in elther plasma Ca, filtered load of Ca or fractional Ca excretion in the control group (I), following PTH Infusion fractional calcium excretion decreased fron $13.0 \pm 2.27$ to $1: 5 \pm 0.37$ (p<0.001) (R1g.I). Decreases in FE Ca were also observed following cAMP infusion ( $18.9 \pm 2.57$ to $9.9 \pm 1.97(p<0.01)$, and DBCAMP $(17.5 \pm 2.97$ c0 $6.9 \pm 0.97$ (p< 0.01$)$. The calculated filtered calciun load was unchanged in each group. A modeat rise in total plasma calciun with PTH $3.6 \pm 0.2$ to $4.1, \pm 0.2 \mathrm{mEq} / 1 \mathrm{p}<0.01$ ) (could not be inileked w1th elther cAMP or DBCAMP. In fact, a anail, buf elgnificant fall in cotal plaena calclum was observed withiDBcAMP (3.5t 0.1 to $3.3 \pm: 0.1$ Eq/1 p $(0.05)$. In al1 groups plava protein fel1; co that the protein bound"' 
conponent of plasana ca presumably aloo tell. The fall In total Ca with DBCAMP may be attributable to this effect rather than ladicating a fall in lonieed plaena Ca. 111. Changes in magnealun hand11ng (Table IV/T18.2) The effect of all the three agent: on ranel $\mathrm{Mg}$ hand11ng was elallar to that on Ca. PTE elgniflcantly Increased cotal plasma magnesiun $(1.6 \pm 0.1$ to $2.3 \pm 0.1$ $m g \pi, p<0.001)$ restoring it to the levels observed $1 \mathrm{n}$, fntect animals. A siaif rise in total plasea Mg was. obgerved with caMp $(1.9 \pm 0.2$ to $2.0 \pm 0.2 \mathrm{mg})$ and DPcaMp (1.5 \pm 0.1 to $1.6 \pm 0.1 \mathrm{mg}$ ) but these changes vere not agnificant. The calculated filtered load of agnesium was not elgaifleantiy itered by PTH or DBCAMP but was. Ingiflcentiy Increased by, CAMP Infusion, Neverthelese, 11ke PTH, (f1ge 2) which decreased FEMg from $15.6 \pm .4 .0$ to $2,3 \pm 1.02$ (p<0.01) both CAMP and DBCAMP e1gnificantly decreased TEMg. $(20.4 \pm 1.9$ to $13.2 \pm 2.57 \mathrm{p}, 0.01$ and

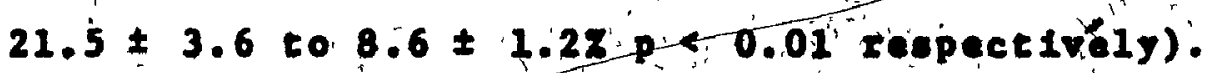

IV. Changes, in phosphate hapdilng (reble $\nabla$ Fig. 3)

A phosphuturic offect was obseryad with all thrae as-

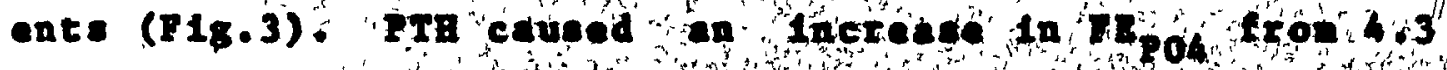

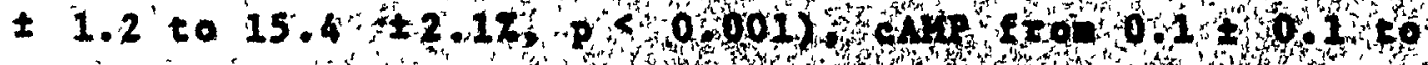


$3.2 \pm 0.97 p<0.02)$ and DBCAMP Erom $2.0 \pm 0.1$ to 12.7 \pm 2.67 ( $p<0.01)$, wh11e no change in FE 104 of the contro1 group $(2.2 \pm 1.0$ to $2.4 \pm 1.4 \%)$ was observed. Plasa phosphate rose throughout the experinent in all groupg of aninals, Including the control. However, there wag no signifleant differance betwean the plase phosphate In the experimental phase of groupa. II, III and IV, and the experinental phase of the, control group I.' Calculated flitered load of phosphace was conetant in all but the DBcAMP treated group, where a onall, but atgnificant r1se was observed (from $11.1 \pm 2.3 \mathrm{pg} / \mathrm{min}$ to $14.6 \pm 2.5$ m8/min.).

v. Effecti of DBCAMP and $\mathrm{Ca} \mathrm{Cl}_{2}$ Infusion (Table YI) DC

In group IV (DBCAMP), a enali but elgnificant drop In plase Ga vas obegrvad. Therefore, these experiments Were repeated on farix aninale Infused with $1.6 \mathrm{mBq} / \mathrm{I}$ Ca $\mathrm{Cl}_{2}$ olution along with DBCAMP in the experimental phase. This infusion of low concentration calciur, prevented a drop in pliena cilctun but did not freluence the PTE-

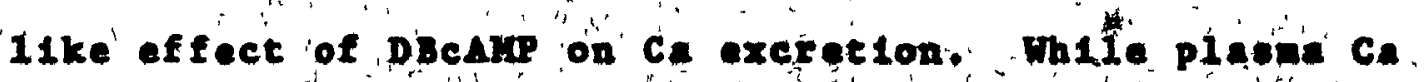

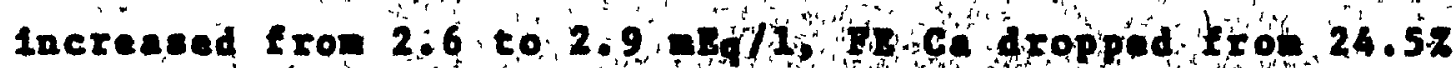

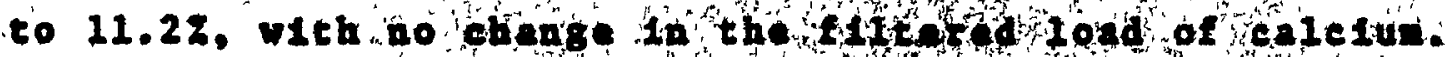

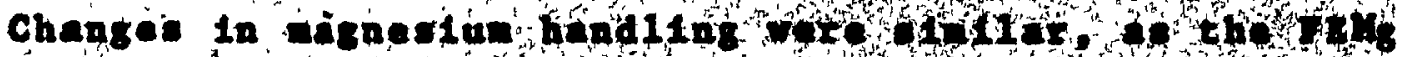

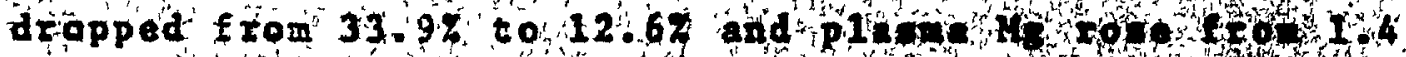
10. 
Chapter VI

DIscosstone

Parathrold hormone 18 knom to produce phospheturia and to reduce calciur clearance in several epecies (Rullman et al, 1960, Amlel et al, 1970, Agus et al. 1973, 81ddulph et al. 1970, Kleenen et 1961). The effecte of the hormone on renal argnesiun bandling aré sinilar to thoce on calclue (MacIntyre ot al'" 1963, Mesry et a1. 1970). The phosphaturic effect of prit lecthought to be mediated via etinulation of renal cortical adenyl cyclase (Chase Aùrbech 1968). PTH seníltive adenyl cyclase has been locellsed In several seguents of the rabblt cortlcal nephron (Chabardes et al. 1975) and durIng PTH Infueton an Increace in the renal excretion of

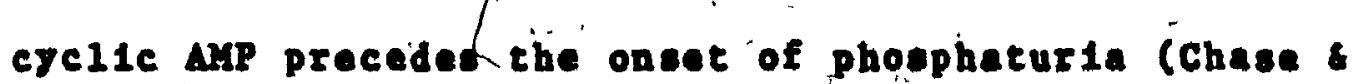
Aurbach 1968). Infuelon of both ejelic AMP and 1ta butsrated derivative have been ghorn to Increase fractional

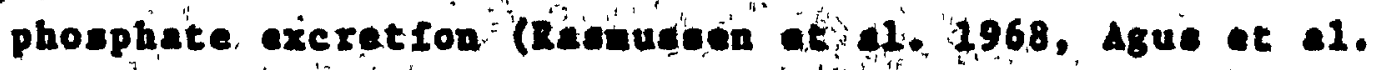
1972. Kuntalser at. 1974):

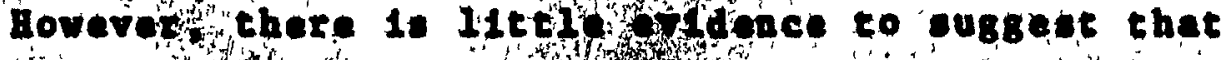

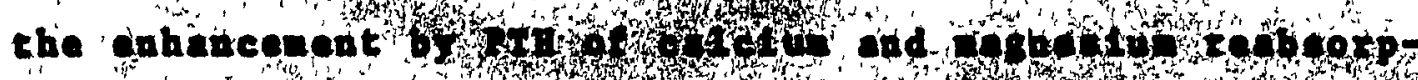

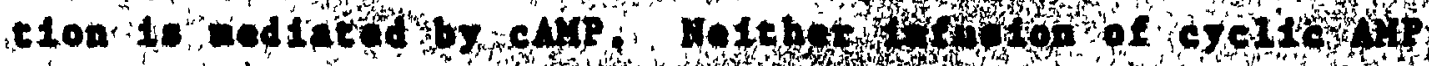


In the ret (Kunte1ger et al. 1974) nor of DBCAMP In the dog (Ague et al. 1972) y18niflcantly reduced calclua clearance. Rasnusien at al. (1968) clatned thet eAKP ainicked the affecte of PTH on calctun but not nagnesiua handligg in the coneclous ret. Howerer, as already-discusced, In thio comparatively long tern experinent, PTE was observed to lacrease rather than decrease calciun clearatuce.

PTa adminletration to IPTX animale generally increaces plasua calclun concentration. Whereas such an effect was shown after cAKP adminlatration in the rat by Wella Lloyd (1969); no increase, was obeervied by Buttlen and Jdrd (1972) and Iuntziger et al. (1974). It 1a probable that the dose of calp used ts of crietcal importance in this respect, as the hypercalcenic responec to cAMp has beed shown to be dose dependent over a relatively narto rangle lWe11s f, Iojd 1969).

- The prenent studies were designed to further 1nventIgete the role of cAMP as a adiator of PTH action. 'The experimente were perforwed 1p, the haveter, to the kidney

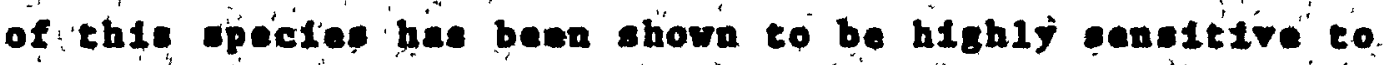

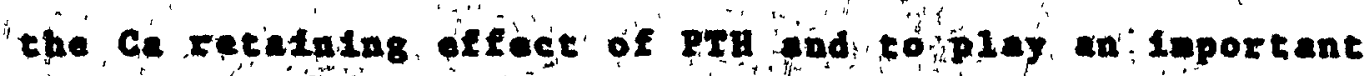

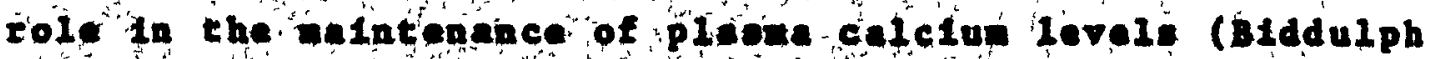

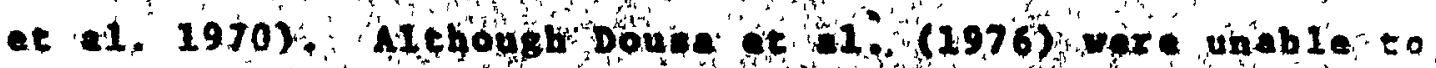


show a phosphaturic effect of PTH in this epectes, we observed that PTI Infusion caused phobphaturia and a decrease In the fractional excretion of both Ca ald Mg. A11 of these effects were ninicked by both caMp and DBCAMP, although the phospheturic affect of cAMP wae lese atriking than that of PTE and DBeAMR. Both nucleot1des ignificantly enhanced tubular reabsorption of Ca and $\mathrm{Mg}$, again the effects of cAMP were less pronounced than these of PTB and DBCAMP. The butjrated derivative decreased the fractional calciun and nagneslun excretion by 667 and 607 respectiely, whereas decreases after CAMP were 487 and 367 .

The doses of the cyclic nucleotides used were sintlar to those shown to produce phosphaturta in rate (Kunte1ger et a1. 1974). The butyrated derlrative of caxip was administered as wil as cAMP as it has beea shown to be" more permeable in certatn tiasues (Posternak ot al. 1962), more resistant to phobphodiesterase (Beerache et al. 1974), and possibly is itself an Inhibitor of phosphodiesterases (Aurbach 1972), which are responglble for the breakdown of cAMP to the physiolog1ea11y. Inert s'AMP. Although carp

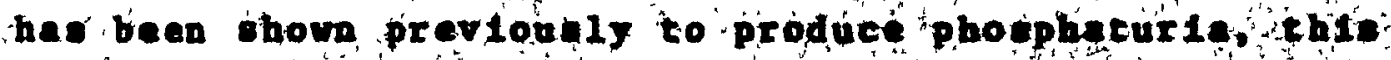

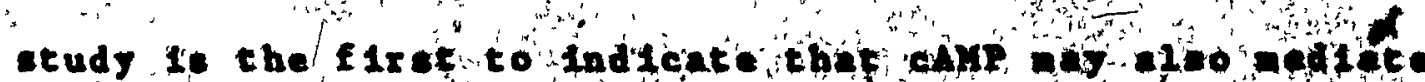

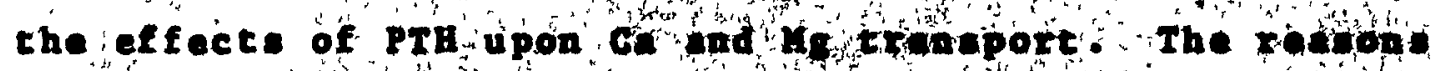

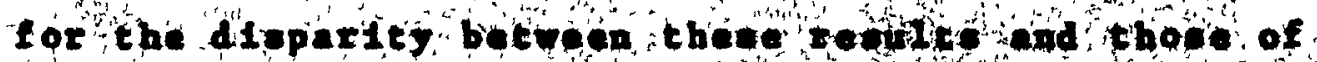
Runteziger et il. 
(1974) In the rat and Agus ot al. (1972) 1n the dog are not apparent, though it ary relate to the reaskable eensitivity of the hanster kidney to the celcium recalning effect of PTH. The increase in total plasma calclum and aagnesiun observed during PIH Infuelon was not observed wth efther nucleot1de. In fact, anal1, but signif1cant decrease in total plasen calciun occurred during DBCAMP although the ultrafilterable calcium aay actually have risen due to the decrease in plasna proteln concentration. However, the decreased fractional excretion of Ca after DBCAMP is unlikely to be due to, a drop in the filtered load, as the calculated flitered load was unchanged. Th1s 18 further supported by the data from/four IPTX hangters which were infused with calciun together with DBCAMP in the adcond phase. The mean piasma ca rose fron 2.6 to $2.9 \mathrm{mEq} / 1$; GRR fron 0.29 to $0.35 \mathrm{~m} / \mathrm{min}$. In splte. of an Increase in calculated f11tered load of Ca from 0.46 to $0.59 \mathrm{urq} / \mathrm{atn}$., the Exactignal excretion of calctun fell from 24.5 to $11.2 \%$. ,There ire beveral pogilible reasone for the fatiure to ohoi a Pro-11ke effect of carp on plasa Ca and Hg. F1ret; changes in lontred or urça (not mea-

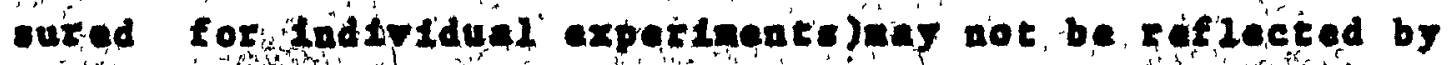

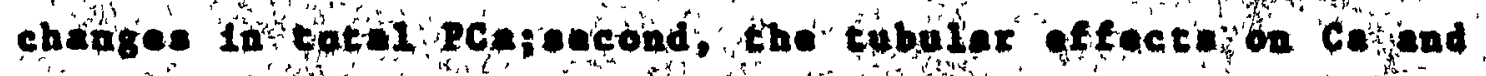

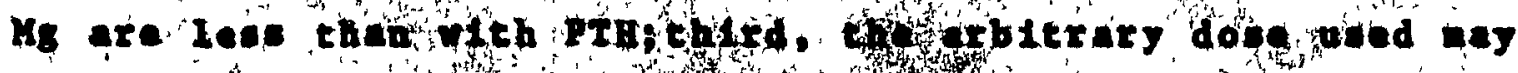


have, been alther too high or too low to completely ainic the effect of PTH (We11. Lloyd 1968) \&nd fourth PTH may cause an Increase in plana Ca and Mg by some renal or extraxenal mechanian not mediated by cAMP. There remaine a fifth possibilty'that PTH any Increase plasma-calclum and magnesium concentration by activation of the adeayl-cyclace syaten, while other effects of cAlp way tend to decrease the plaser levels of/ these electrolytes. Certalniy cAMP is knoin to mediate the actions of many other hormones including ADH which acts primarily in the renal medulla (Chise Aurbach 1972), and calcitonin which generally acta in an opposte direction to PTB on calcium netabolian. (Heath Aurbach 1974).

The tubufar location of these medlatory effects of CAMP is at present unknown. Micropuncture experiments in the dog suggeet that the Ca retaining effect of PIH 18 beyond the proxinal tubule (sutton et al. 1976) wh1le pre-

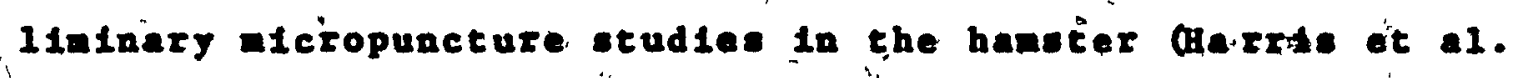
1976) auggest that PTH act at sereral attes in the nephronthe proximal tubule, accending limb of Henle's 100p and in the terainal part of the nephron. Further experinente are requited to deterinine whether cakp to active in the red-

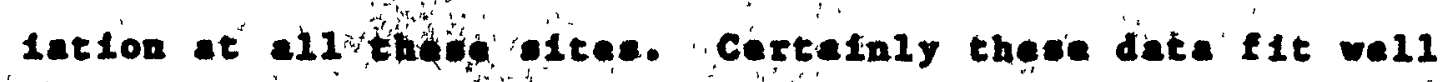
wth those of Chabprace et al, (1975) who domondtrated the 
presence of PTH sensitive adenyl cyclase activity in the proxinal convoluted tubule and pars rectas the thick ascending 11mb of Henle, loop, the distal convoluted tubule (to a leser extent) and the first cort1cal segment of the collecting duct.

The reason for the licrease in pleana phosphate concentration throughout each experinant Including the TPTX controls is not known. Perhape this is a function of diurnal variation, as it has been shown that in the rat, plasma phosphate rises through the day, despite a concomitant rise In endogenous PTH levels (Cohn 1970, Mudge et al. 1973). However, ac suggested by Blddulph et al. (1969), who observed a elatiar rise in plasma phosphate after PTh adminletration to the intact haneters, but not in the rat, it may reflect the existence of a different phoophatur $1 \mathrm{c}$ achanism in this species.

In present atudies hovever, the observed rise In plasea phorphate could not account for the phosphatur 1a a there was no wich increase in the fractional phosphate excretion in the control group.

The differenges in the base line excration of the electrolytes In different group cunnot be explatied elther,

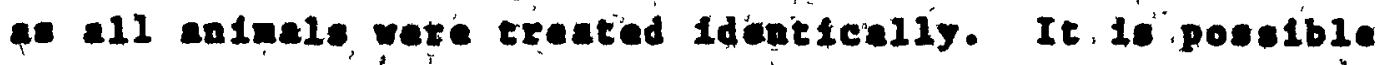
that, as the etabolign of this gige of andaid it relitively 
53.

fact, any variation In dilly food Intake could change the urinary output of electrolytes. Also there may. have been differences In the completeness of the parathyroldectomy between these groupa. 
Sumary - Contribution to original knowledge.

- Although the accumulating evidence stongly aggests that the mechanisa of action of PTH on the renal tubular transport of phosphate lnvolves cAMP, this otudy presents the flrst clear evidence thet cAMP way bediate the effects of PTH not only on renel phosphate handilng but also that of calcium and magnesium. Both CAMP and DBCAMP were shown to enbance tubular reabsorption of calctun and magnesiun and to reduce that of phosphate. The quantitative differences in the urinary data and lack of PTH-like effects of elther nucleotida on plasna calciun and agnesiun levels nay be due to the arbitrary doses of cAMP and DBCAMP used. A dose-response sudy would resolve thls problem. Purther ctudiea are also required to locallse these renal actions of canP. 


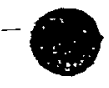

\section{TABLE I .}

\section{COMPARISON OF INTACT AND TPTX HAMSTERS}

\begin{tabular}{|c|c|c|c|c|c|c|c|}
\hline & & tac & $(n=8)$ & TPT & $\mathbf{T X}$ & $(n=8)$ & $\mathbf{P}$ \\
\hline BetX & 54.0 & \pm & 1.0 & 53.0 & \pm & 1.0 & NS \\
\hline Prot. $\mathbf{8 X}$ & 4.5 & \pm & 0.1 & 4.6 & \pm & 0.1 & NS \\
\hline $\operatorname{GFR}(m 1 / m i n)$ & 0.32 & \pm & 0.08 & 0.29 & \pm & 0.03 & NS \\
\hline$v(\mu I / m i n)$ & 3.9 & \pm & 1.2 & 3.2 & \pm & 0.5 & NS \\
\hline P Ca $\left(\mathrm{mEq}_{\mathrm{q}} / \mathrm{L}\right)$ & 5,1 & \pm & 0.3 & 2.9 & \pm & 0.1 & $<0.001$ \\
\hline$P$ Kg (mgx) & 2.4 & \pm & 0.1 & 1.6 & \pm & 0.1 & $<0.02$ \\
\hline $\mathrm{P} \mathrm{PO}_{4}$ (mg & 3.2 & \pm & 0.7 & 4.5 & \pm & 0.7 & NS \\
\hline FE Ca $(x)$ & 2.8 & \pm & 2.0 & 11.9 & \pm & 1.6 & $<0.001$ \\
\hline FE $18(x)$ & 5.4 & \pm & 1.8 & 18.7 & \pm & 2.5 & $<0.01$ \\
\hline $\mathrm{FE} \mathrm{PO}_{4}(\mathrm{x})$ & .41 .6 & \pm & 6.9 & 2.9 & \pm & $\begin{array}{r}0.9 \\
\end{array}$ & $<0.001$ \\
\hline
\end{tabular}

Results are mean \pm S.E.M. 
Q

TABLE II

HEMDYNAMIC EFEECTS OF PTH, CAMP AND DBCAMP

GROUP' I GROUP IÍ.

TPTX- : CQ TPTX + PTH

$\begin{array}{rrr}\text { Het.7 } \because \quad 53.0 & 51.0 \\ \pm 1.0_{\text {\#* }} \circ \pm 1.0\end{array}$

Prot. gx:

$$
\begin{array}{rr}
4.6 & 3.9 \\
\pm 0.1_{* \star \star} & \pm 0.2
\end{array}
$$

GFR

ml $/$ min

$0.29 ; 0.29$

$\pm 0.03 \pm 0.05^{\circ}$

Urine Fov Rate $3.2, \quad 2.8$

$\mu 1 / \operatorname{mln}$

$\pm 0.5$

$\pm 0.5$

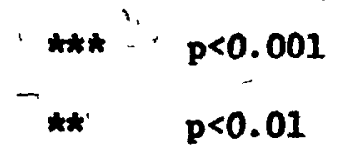

GROUṔ IIT

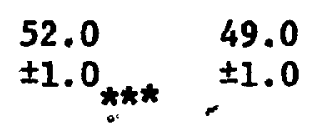

$4.5-3.9$

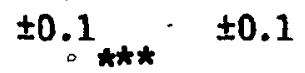

$0.34 \quad 0.32$

$\pm 0.06 \quad \pm 0.05$

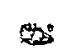

$2.9-2.9$

$\pm 0: 3$

$\pm 0.2$

92

$\cdot 1.9$ $\pm 0.2$
GROUP IV

TPTX + DBCAMP

$53.0 \quad 51.0$ \pm 1.0 *t \pm 1.0 $4.7 \quad 3.9$ $\pm 2.7+20.1$ 0.25
\pm 0.03 $\quad \begin{array}{r}0.27 \\ \pm 0.02\end{array}$ $\pm 0.03 . \pm 0.02$

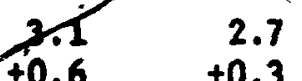






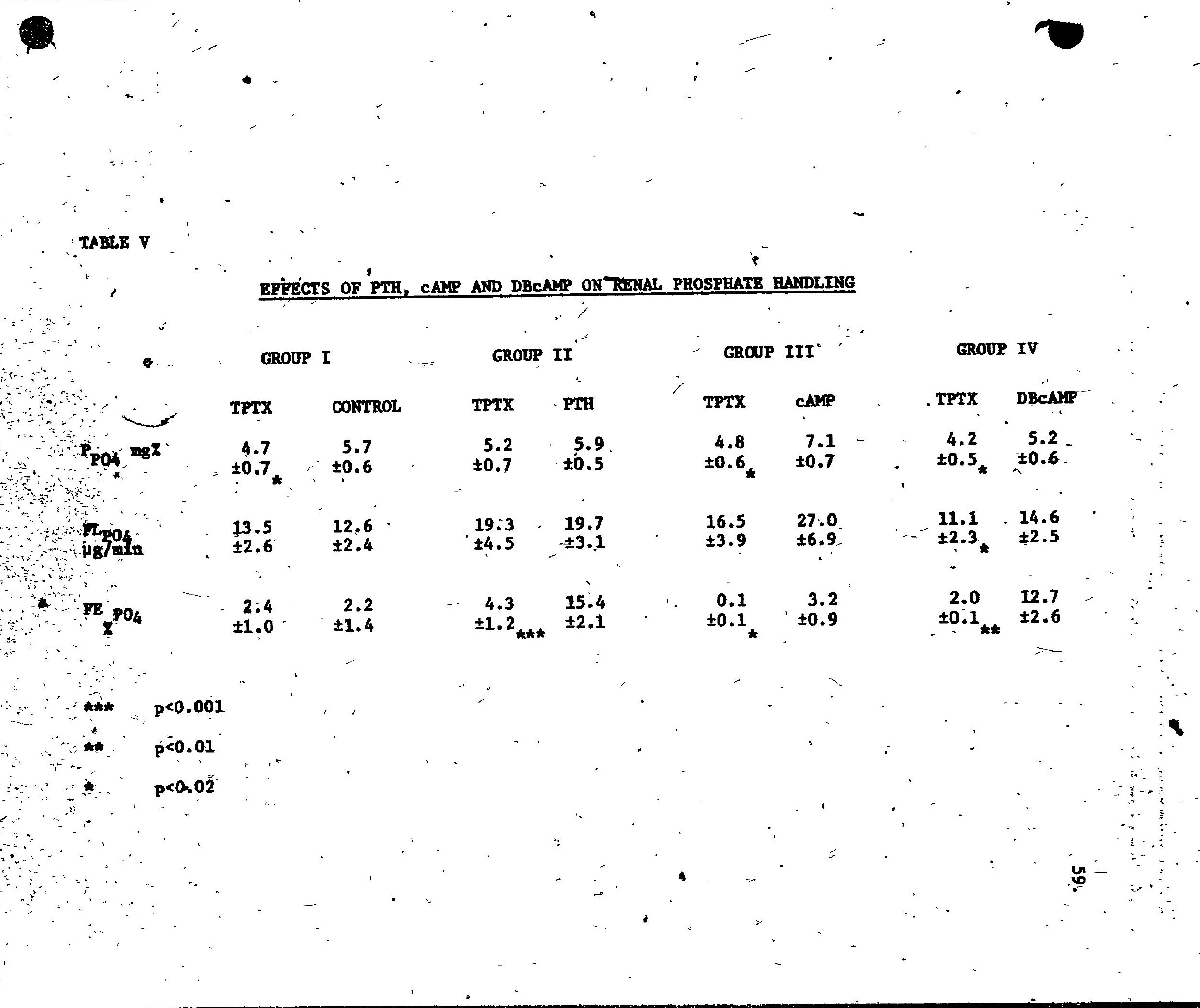




\section{TABLE VI}

\section{EFFECTS OF DBCAMP ON RERAL MANDLING OF CAICIUM AND MAGESIUM WTTH}

$1.6 \mathrm{mEg} / \mathrm{h}$ CALCIOM CHLORIDE INIYOSION IN TEE BXPERTMENTAL' PEASE

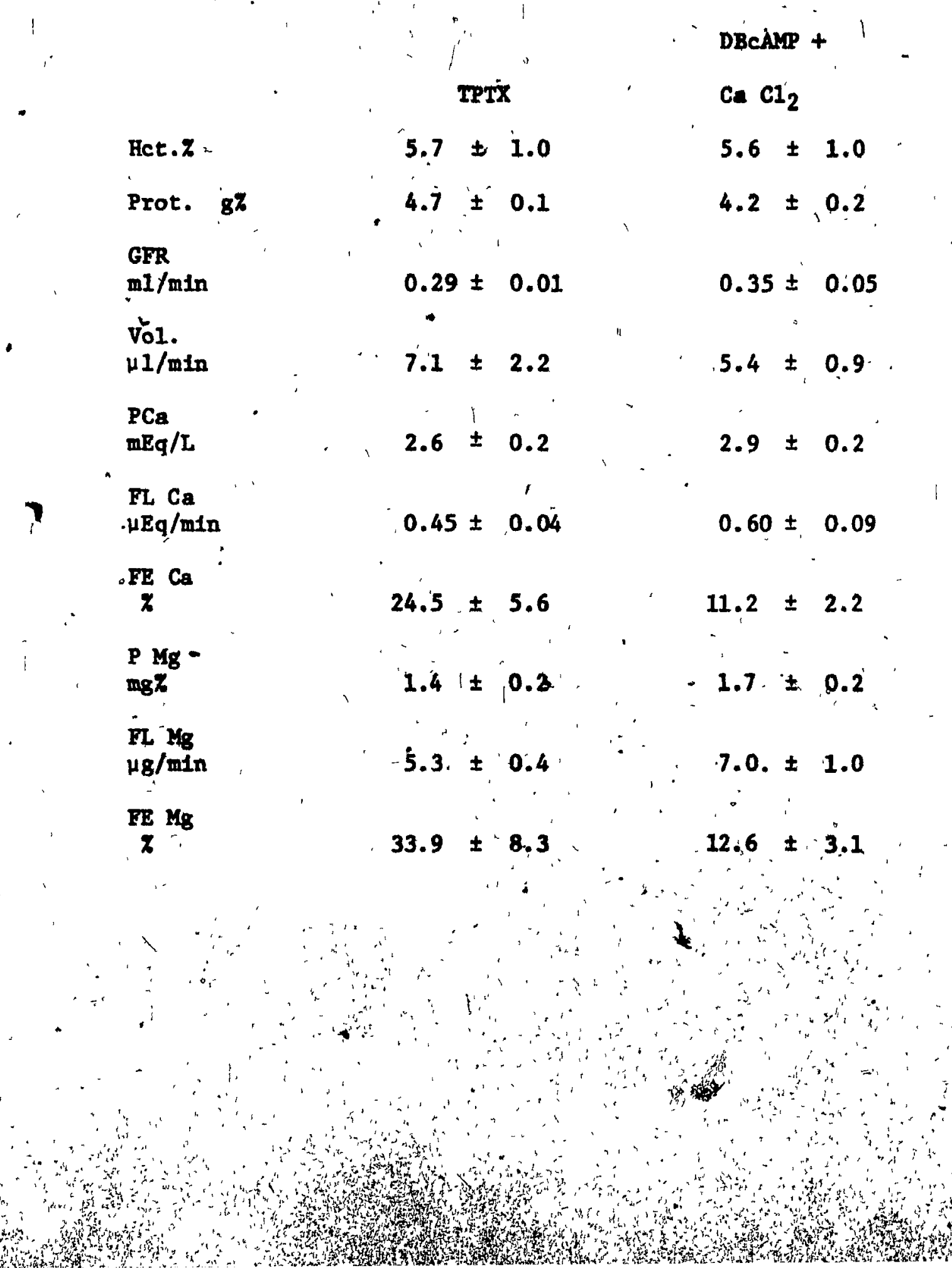




\section{$\square$ Control phase} Experimental phose

$* * * p<0.001$,

$* P<0.01$

$\mathrm{FE}_{\mathrm{Co}}$

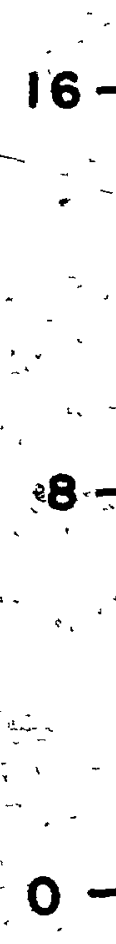




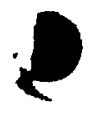

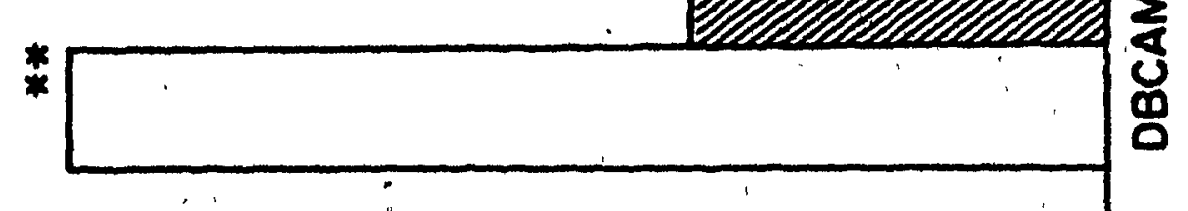

62.
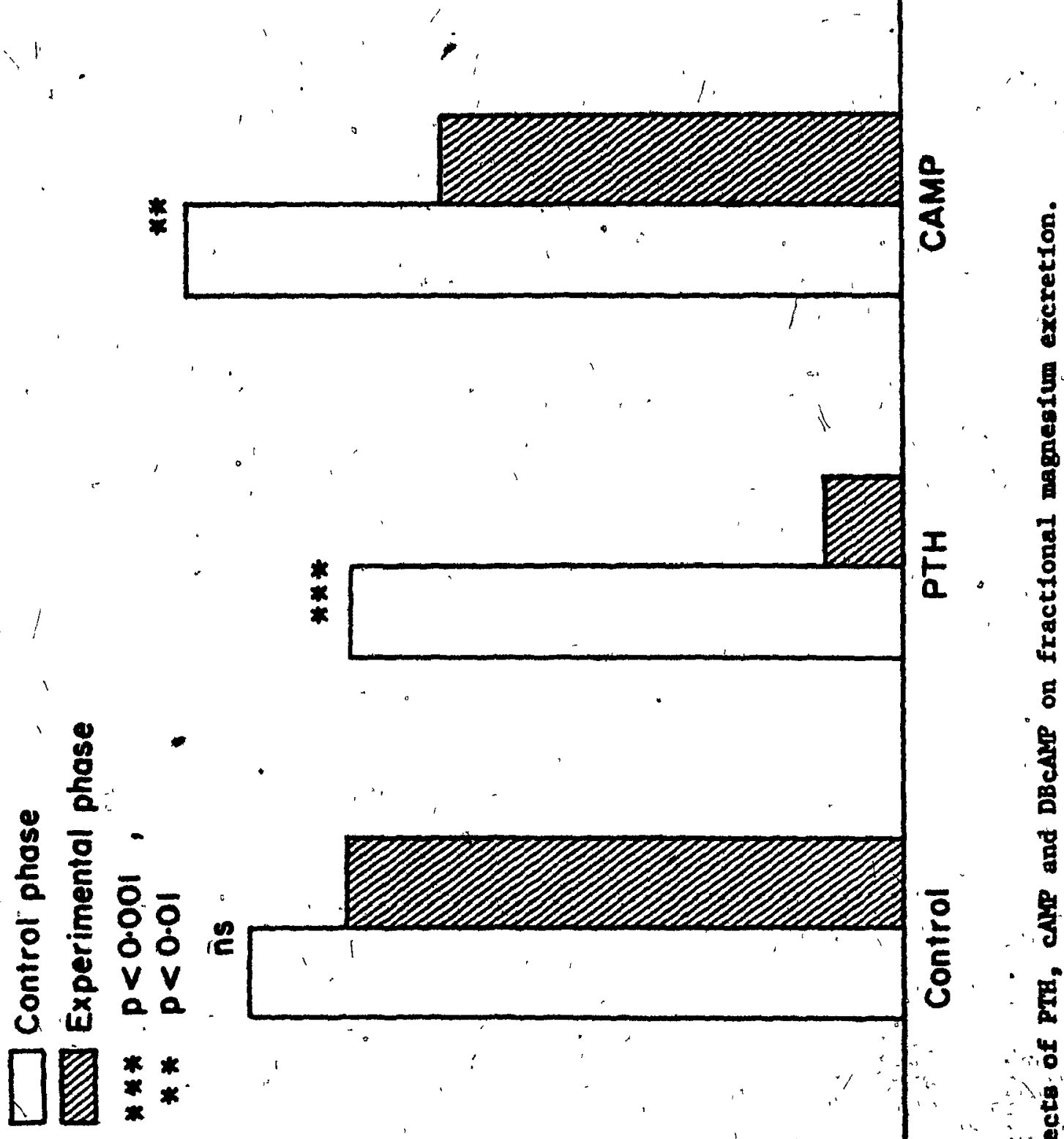

운

$\therefore$

$\therefore \quad 40$

量

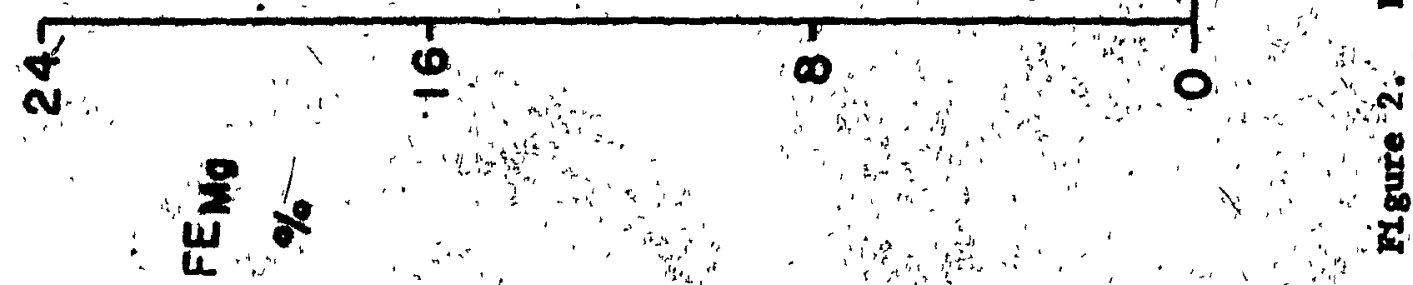




\section{BIBL IOGRAPEY}

1. Agus, J.B., D.B. Puschet, D. Senesky, M. "Coldberg. Mode of action of PTH and cyclic adenoaine 3'5 monophosphate on renal tubular phosphate reabsorption in the dog. J. C1In. Invest. 50: 617-626 (1971).

2. Agus, J.B., L. B. Gardnèr, L. H. Beck, M. Goldberg. Effects of parathyrotd horwone on renal tubular reabsorption of calcium, sodium and phosphate. fim. J. PhysLol. 1143-1148 (1973).

3. Albright, F., Reifengtein, B.C, Jr. "The Parathyroid Gland and Metabolic Bone Disease". Williams \& Wilkins Company, Baltimore, p.13-23, 1948.

4. Amiel, C., H. Runtz1ger, G. Richet. Micropuncture study of handling of phosphate by proximal and distal nephron in normal and parathyroidectomized rats. Evidence for distal. reabeorption. Pflüger Arch. 317: 93-109 (1970). *

5. Amfel, C., H, Kuntziger. Renal Tubular handling of phosphate. In les Co11oques - (Inserm. 30: 37-50, 1974).

6. Aurbach, G.D. Isolation of parathyroid hormone after extraction with phenol. J. B1ol. Chen. 234: 3179-3181 (1959).

7. Aurbach, G.D., Marcua, R. ,Heersche, J;H.M., Wintckoff, R.N. Mars SH. Cyclic nucleotides in the action of native and oynthet ic parathyrold and calcitonin peptides. "In 
parathyrold hormone and the calcitonins; ed. Talmage, R.V. Munson, P.I., Amsterdam Excerpta Medica Foundation p.502-510, 1972.

8. Aurbach, G.R, Keutman, H.t, , Näll, M.D. Tregear, G.W., O'Rlordan, J.L.N., Marcus, R., Marx, S.J., Potte, J.T. Jr .

- Structure, synthesis and mechanism of action of parathyrold "hormone. Recent Progr. Horm. Res. 28: 353-398 (1972).

9. Aurbach, G.D., Heath, D.A. Parathyrold Hormone and Calcitonin regulation of renal function. Ridney Int. 6: 331-345, 1974.

10. Aver111, C.M. and Heaton, F.W. The renal handling of magne81um. Clin. Sci. 31: "353-356 (1966).

11. Barcklay, J.A., Cooke, W.T., Kenney, R.A. The renal excretion of Inorganic phosphate In man and dog. Acta Med.' Scand.' 134: $107-116$ (1949).

12. Barnicot, N.A., The local action of parathyrold and other tisaues on bone in the Intracerebral grafts. Journal of Anat. 82: 233-248 (1948).

13. Barter, F.C., The effect of the parathyrold in phosphate excretion. In "The Parathyro1ds" ed. Greep, R.0. and Talmage, R.V. Springfield, Illinols: Thomas. p.388-405, 1961.

14. Beck, L.M., Goldberg, M. Effects of acetazolamide and parathyroldectomy on renal transport of codiun, calctum and phosphate. Am. J. Physiol. 224: 1136-1141 (1973). 
15. Bethune, J.E., Turpln, R.A., Ingue, H. Effects of parathyrold hormone extract on divalent ion excretion in man. J. Ciln. Endo. Metab.. 28: 673-678 (1968).

16. Biddulph, D.M., Hirsch, P.F., C.W. Cooper and P.I. Mupson. Effect of thyroparathyroldectomy and paratbyrold hormone on urinary excretion of calcium and phosphate in the golden hamster. Eindocrinology 87: 1346-1350 (1970).

17. Biddulph, D.M. Gallimore, L.B. Jr. Sensitivity of the kldney to parathyrotd hormone and 1ts relatiohship to serum calcium in the hremster. Endo. 94: 1241-1246 (1973).

18. Bldduiph, D.M.," Hirsch, P.F., P.L. Kunson. Thyrocalcitonin and parathyroid hormone in the hamster. In Calcitonin, Prncegedings of the Second International Symposium. Ed. Taylor, S., G Foster p.392-399 (1969).

19. Bifvoet; O.L.M. Relation of plasme phosphate concentration to renal tubular reabsorption of phosphate. c1in. Sc1. 37: 23. (1969).

20. Brewer, H.B. Jr., Fairwell," T., Ronan, R., Slamore, G.W., Arnaud, C.D. Human parathyrold hormone: amino actd sequence of the anjo terminal realdues 1-34. Proc. Kat. Ac. Sc1. USA 69: 35853588 (1972).

21. Brunette, M., Wha, S.F., Evantion, R.L., D1rke, J.H. MHeropuncture atudy of angnesiun reabrorption in the proximal tubule of the dog. 4. J. Phya101. 216: 1510-1516 (1969). 
22. Brunette, M. Aras, D.M. A microinfection study of nephron permeáb1lity to calclum. and magnesium. Am'. J. Phystol. 221: 1442-1448 (1971).

23. Brunette, M.G., L. Taleb, Carrfere, S. Effects of parathyro1d hormone on phosphate reabsorption along the nephron of the rat. Am. J. Physio1. 225: 1076-1081 (1974).

24. Buckle, R.M., Core, A.D.; Cooper, C.W., Gitelman, H.J. The Influence of plasma magnesium concentration on parathyrold hormone secretion. J. Endo. 42: 529-534 (1968).

25. Bulger, H. A., Gausmann, F. Magnesium metabolism in hyperparathyrold18m. J. Clin. Invest. 12: 1135-1142 (1933).

26. Butcher, R.W., Sutherland, E.W. Adenosine 3'5', phosphate in biological materials. I. Purifications and properties of cyclic 3'5' nucleotide phosphodiesterase and use of this enzyme to characterize adenosine $3^{\prime} 5^{\prime}$ phosphate in human urine. J. B1ol. Chen. 237: 1244-1249 (1962).

27. Buttlea, D., Jard, S. Renal handling $3^{\prime} 5^{\prime}$ cAlP in the rat. The poseible role of luminal $3^{\prime} 5^{\prime}$ - cyclic AMp in the tubular reabsorption of phosphate. Pflügers Arch. 331: 172-190 (1972).

28. Carrasquer, G. and Brodsky, W.A. Transient secretion of phosphate In relation to underlying plasma level in the dog kidney. Am. J. Phys101. 199: 1239-1243 (1960).

29. Chang, H. Grafts of parathyrold and other tisaues to bone. Anat Record 111: 23-48 (1951). 
30. Chabardes, D., Imbert, M., Clique, A., Montegut, M., Mórel, F. PTH sensitive adenyl cyclase activity in different segments of rabbit nephron. Pflugers Arch. 354: 229-234 (1975).

31. Chase, L.R. Aurbach, G.D. Parathyroid function and the renal excretion of $3^{\prime} 5^{\prime}$ adenylic ac1d. Proc. Nat. Acad. Sc1. 58:

1 518-525 (1967).

32. Chase, L.R. and Aurbach, ;.D. Renal adenyl cyclase: Anätom1cally separate sites for parathyrold hormone and vasopressin. Sclence (Washingţon) 159: 545-547 (1968).

33. Chase, L.R., Melson, G.L., Aurbach, G.D. Pseudo-hyparathyroid18m, defective excretion of $3 \mathrm{~S}^{\prime}$ ANP in response to PTH. J. $\therefore$ Clin. Invest. 48: 1832-1844 (1969).

34. Chen, P.S. Jr., Tortbara, T.G., and H. Warner. Microdetermination of phosphorus. Anal. Chem. 28: 1756-1758 (1956).

35. Chu, L.L.H., MacGregor, R.M. Nast, C.S., Hamilton, J.W., Cohn, D.V. Studles on the blosynthesis of rat parathyrold hormone. and proparathyrold horwone adaptation of the parathyrold glands to dietary reatriction of calcium. Endo. 93: 915-924 (1973).

36. Coburn, J.V., Massry, S.G., Kleeman, C.R. The effect of calclum Infusion on renal handling of magnesium with normal and reduced glomérular filtration rate. Nephron 7: 131-143 (1970).

37. Cohn, C.W. Diumal rhythms in urinary electrolyte excretion by the rat. Life Sc1. 9: 803-808 (1970).

38. Collip, J.B. The extraction of parathyrold hormone which will prevent or control parathyrold tetany and which regulates the level of blood calciui. J. Blol. Chem. vil. 63: 395-438 (1925). 
39. Cramer, C.F. Sulker, A.P., Copp, D.H. Parathyrold influence on, calcilum and phosphor us absorption by the gut. In the Parathyroids. Ed. R.O.'Greep \& R.V. Talmagè. p.158-166 (1961).

40. D1 Bella, F.P. Dousa, T.P., M1ller, S.S., Arnaud, C.D. Parathyrold hormone receptor $s$ of renal cortex: Specific binding of blologically active $125 \mathrm{I}$-labeled hormone and relationsh1p to adenyl-cyclase activation. Proc. Nat. Acad. Sc1. 71: 723-726 (1974).

41. Dousa, T., Rychllk, I. The effect of parathyrold hormone on . adenyl cyclase in rat kidney.' Blochem. B10. Phys. Ach. 158: 484-486 (1968).

42. Dousa, T.P., Pre1ss, J., Ktm, J.K., Hu1, Y.S.F., Knox, F.G. Activiation of CAMP system and protein kinase (PK) by parathyroid hormone (PTH) and calcitonin (CT) without phosphaturia In hamster. Clin. Res. 24 p. 399 A (Abstract) (1976).

43. Edward8, B.R., Suttion, R.A.L., Dirks, J.H. Effect of calcium Infusion on reffal tubular reabsorption in the dog. Am. J. Physiol. 227: 13-18'(1974),

44. Blsenber8, E. Renal effects of parathyrold hormone. In Parathyroid hormone and Thyrocalcitonin. Ed. Talmage, R.V. Belanger, L.F. Excer ptá Medica Amsterdam. pp.465-475 (1965).

45. E11sworth, R., Nicholson, W.M. Further observations upon the changes in the electrolytes of the urine following the infection of parathyrold extract. J. CIIn. Invest. 14: $323-827$ (1935). 
46. Fang, V.S., Tasshian, A.M. Jx. Stud les on the role of the liver In the metaboliam of parathyro1d hormone. Effects of partial

- hep atectomy and Incubation of the hormone with tisaue homogenate. Endo. -90: 1177-1184 (1972).

47. Flscher, J., Oldham, S., S1semore, C., Arnold, C. Calclumi "regulated parathyrold hormone peptidase. Proc. Nat. Açad. Sc1. U.S.A. 69: 2341-2345 (1972).

48. Forte, L.R. 'Characterlzation of adeny1-cyclase of rat kIdney plasma membrane. B1och.' B1oph. Acta 266: 524-542, (1972)

49. Frick, A: Proxthal tubular reabsorption of Irorgantc phosphate during saline infusion in the rat. Am. J. Phystol. 223: 1034$1040(1972)$.

50. Frick, A: et al. Microperfusion study. of, calctum tran'sport' in the proximal tubule of the rat kidney. Pflägers Arch. 286: 109-117 (1965).

51. Frick, A. Metchanism of Inorganic phosphate diuresis secondary to saline Infusions in the rat. Pflugers Arch. 313: 106-110 (1969).

52. Fuhr, J., J. Raczmarczyk and 'C.D. Kruttgen. EIne einfache 'colorimetrische Methode' zur Inulinbestimming fur Nierenrclearance - untersuchügen bel Stoffwecheselgésunden Diabetikern. 'RIIn. Wochschr. 33: . 729-730 (1955). Gatllard, P.J. Parathyroid and bone In t1sisue culture. In the Parathyro1ds. Ed. 'Greep, R.o.' 'and Talmage, R.V. 'pp. 20-45', Springfleld, Iliinols (1961). 
54. Goldberg,M., Beck, L.M., Puschett, J.P., Schubert, J.J. site of action of Benzothlad lazt? Furboemide, Ethacryilc Ac1d.; In Modern Diuretic Therapy. Excerptá Med 1ca, Amsterdam p. 135 (1973).

55. Greenber8, D.M., Mackey, M.A. The effect parathyrold extract on blood magnestum. J. B1ol. „Chem. 98: 765-768 (1932).

56. Greenwald; I., Gross, J.' The effect of administration of a potent -parathyro'id extract upon the excretion, of nitrogen, phosphorous calcium and magnesium with some remarks on the solublitty of calctum phosphate in serum and on the pathogene81s of tetany. J. B1ol. Chem. 66: 217-227 (1925).

57. Habener, J.F., Kemplier, B., Potts, J.T. Jr. .' Rich, A. Proparathyrold hormone: blosynthesis by humin parathyroid adenomas. Sclence 178: 630-633 (1972).

58. Hamburger, R.J., Lawson, N.La, Den1s, J.W. Effects of cyc1Ic adenósine nucleotides/on fluld absorption by different segments of proximal tubule. Am. J!'Physio1. 227: 396 (1974).

59. Hamilton, J.W., Splerto, F.W., MacGregor', R.M., Cohn, D.V. Studies on the blosynthesis in vitro of parathyrold hormone. II. The effect of calclum and magnesium on synthesis of para-. thyrold hormone 180lated from bovine parathyrold t18sue and Incubation medium. J. B101. Chem. 246: 3224-3233 (1971).

60. Handler, J.S. A study of revial phosphate excrettion in the dog. Am. J. : Phya1o1. 202: 787-790 (1962) 
61. , Harr 18, C.A., Baer, P.G., Chłrto, E., Dirks, J.H.' Compositton of mamalian glomerular filtrate. Am. J.' Physiol. 227: 972 (1974).

62. Harris, C.A., Buxnatowska, M., Sutton, R.A.L., and Dirks, J.H. "Evidence for parathyrold hormone (PTH) enhancement of calcium 'and wagnegium reabsorption in the terminal nephron segment of the hamster. A Clin. Res. 24401 A (Abstract) (1976).

63. Heaton, $F, W$. The parathyrold glands and magnesium metabollom In the rat. J. Clin. Sc1. 28: 1543-553 (1965).

64. Hellman, D.E., Baird, H.R., Bartter, E.C. Kelationship of maximal tubular phosphate reabsoxption to filtration rate of the dog. Am. J. Physiol. 207: 89-96 (1964).

65. Heersche, J.N.M., Fedak! S.A. and Aurbach, G.D. The mode of action of dibutryl. adenosine $3^{\prime} 5^{\prime}$ monophosphate on bone tissue In vitro. J. Bloi. Chem. 246: 6770-6775 (1971).

66. Heersche, J.N.M., Marcus, R. and Aurbach, G.D. Calcitonin and the formation of $3^{\prime} 5^{\prime}$ - AMP In bone and pkidney. Endo. 94 : 241-247 (1974).

67. Hellman, D.F., Au, "พ.v.W., Bartter, F.C. Evidence for a direct affect of parathyroid hormone on urinary ac1dification. im. J. Physiol: 209: 643-650 (1965).

68. : Henion, W.F., putherland, E.V., Posterny, T.B. derivatives of adenosine $3^{\prime} 5^{\prime}$ - phosphate on IIver ilces and tntact anima1s. Btoch. Btoph: Arch. 148: "106-110 (1967).

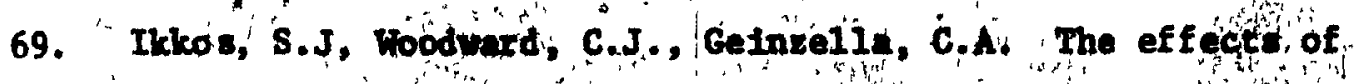
human growth hothone in man. Act ando. 32. 341 (1959) 
70 Kalu, D.N., Hadj 1 Georgopoulos, A., Sarr, M.G., Solomon, B.A., Foster, G.V. Role of parathyrold hormose in the maintenance of plasma calcium levels in rats. Endo. 95: 1156-1165 (1974).

71. Kamineky, N.L., Broadus, A.E., Hardman, J.C., Jones, D.V. Jr. Bal1, J.H., Sutherland, E.W. and I1ddle, G. Effects of parathyrold horwone on plasma urinary, adenosine $3^{\prime} 5^{\prime}$ monophosphate in man. J. C11n. Inyest. 49: 2387-2395-(1970).

72. Kenny, A.D., Heiskell; C.A. 'Effects of crude thyrocalcitonin on calcium and phosphorous getaboliem in rats. Proc/ Sc1. Pxp. 401. Mod. 120: 269 (1965).

73. Reutmann, H.T., Daweon, B.E., Aurbach, G.D., Pott8, J.I. Jr. A blologically active amino-terminal fragment of boolne payathyrold hormone prepared by dilute actd hydrolysis. Biochen. 11: 1973-1979 (1972).

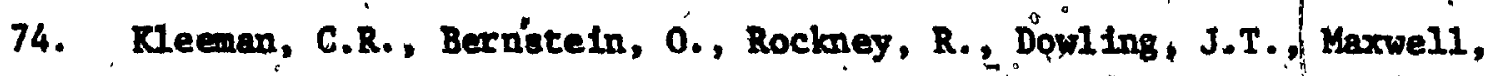
M.H. Studies on the renal clearance of diffusable calctuh and the gole of the parathyrold glands in Its regilation. Tale J. Biol. Med. $34:$ Fo (1961).

75. Kinne, R., Shalth, L.J., Kinine-Saffran, R., Schwartz, I.L. Distribution of membrane bound cyclic AMP dependent protéfin Kinase in plasma membranes of cells of the ktdney cortgk. J. Mab. $101.24: 145-159$ (1975):

76. Krox, G. Gechone, C. piftal cite of uetton of parathyroid

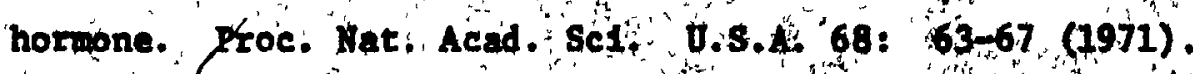


77. Lambert, P.P., Vendervetken, F., Dekosler, J.P., Kohn; R.J., DeMyttelnaere, $K$. study of phosphate excretion by the otop flow techniqque. Nephrion 1: 103-117 (1964).

78. Kuntz1ger, H., Amiel, C., Rolnel, N., and Morel, F. Effects of parathyroldectory, and cyclic AMP on renal transport of phosphate, calcium and magnestum. Am. J. Phyàtol. 227 : 905-911 (1974).

79. Lassiter, E., Gottschalk, C.W., Mylle, M.' Micropuncture otudy 1 of renal tubule reabsorption of calcium in normal rodents. Am. J. Physiol. 204: 771-775 (1963).

80. Le Grimellec, C., Roinel, N. Y Morel, $\dot{F}$. Simultaneous magnegium calclum, phosphorus, potassium and chloride, analysis in rat 'tubular fluld. IV: During acute plasma phosphate loading.

¿Pflügers Arch 346́: 189-194 (1974).

81. Levinsky, H.G., Davidson, D.G. Renul action of parathyrold extract in the chicken. "An. J. Phystol. 191: 530-536 (1957).

82. Maccallum, พ.B., Voegtiln, C. On the relation of tetany to the parathyrold giandis and to calcium metaboliam. J. Exp. Med. 11: 118-151 (1909).

83. MaçIntyre, I., Boss, I., Troughton, V.A. Parathyrold hormone and magnestum homeostasis, Natuxe 198: ;058-1060 (1963).

84. Mras, R., Aurbach, G.D. Adengl cycláce frov renal cortex. BLoch. B10ph, Acte 242:' 410-421 (1970).

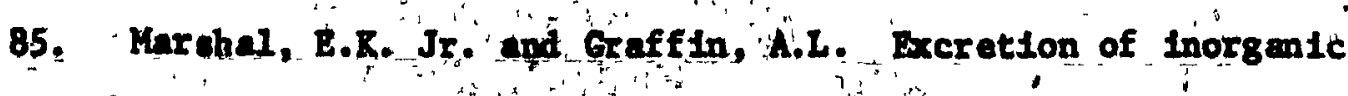

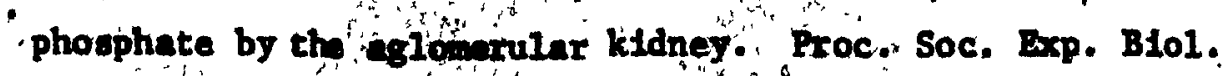

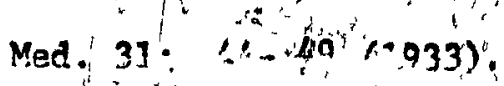




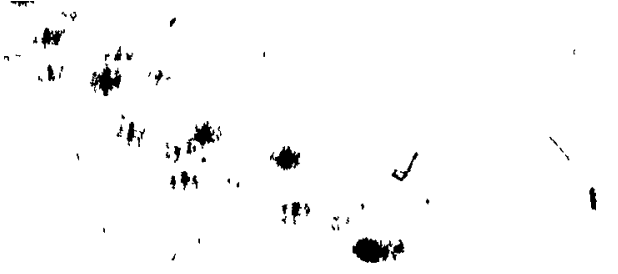

86. Marx, S.J., Fedak, S.A., Aurbach, G.D. Praparation and characterlzation of a hormone responsive renal plasma membrane fraction. J.B10 . Chem., 247: 6913-6918 (1972).

87. Massry,-S.G., Coburn, J.W., Kleeman, C.R. The linfluence of. extracellular volume expanaton on renal phosphate reabsorption in the dog: J. Cin. Invest. 48: 1237-1245 (1969). .

88. Massry, S.G., Coburn, J.W. and Kleenan, C.R. Renal handling , of magnesium in the dog. Am. 'J. Physiol, 216: 1460-1467 (1969).

89. Masery, S.G., Coburn; J.W., Chapman, L.W.; Kleeman, C.R. Role of serum calcium, parathyrotd hormone, and NaCl Infuston on renal Ca and Na clearancep, Am. J. Phys101. 214: 1403-1409 (1968).

90. Melick, R.A., Aurbach, G.D., Potts, JJ.T. Jr. Distribution and half $11 f e$ of I. 131 - Labelled parathyrold hormone in rat: Endo. 77: 198-202. (1965).

91. Mendel, L.B., Benedict, S:S. Bvidence for relation between metaboliam of magnestum and calctum In animals. Amer. J. Physiol. 25: 1323 (1909).

92. Meison, G.L., Chase, L.R., Aurbach, G.D. Parathyrold hormone sensitive adenyl cyclase in 1solated renal tubules. Endo. 86: 511-518 (1970).

93. Moriel, F., Roinel, N, LeGrimellec, C. Electron probe anaiysts of tubular fluld composition. Véphron, 6 350-304 (1969).

94. 'Mudge, G.H., Barndt, W.V., Valtin, M. Tubuiar traneport of urea, glucose; phosphate, uric actd, sulphate and thlobulplinte: In Orloff, J. and P.W. Berliner. Handbook of Phydtology Renify
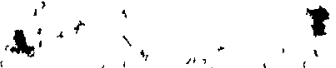
Physlology, Williams and W1lliamson, Baltimore p.587-752 (1973).

95. Muldowney, F.P., Carrol, D.V., Donohove, J.F. and Freoney, R. Correction of renal bicarbonate wastage by parathyroldectomy Q.J. Med. 40: 487-491 (1971)

96. Murayama, Y., More1, F., LeGrimellec, C. Phosphate, calctum and magnestum transfers in proximal tubules and loops of Henle as measured by single nephron microperfusion. Pflügers Arch. 331: $1-9$ (1972).

97. Murdough H.V.J. and Robinson, R.R. Magnestum excretion in the dog studied by stop-flow analysis. Am. J. Physiol. 198: "571$574(1960)$.

98. Nordin, Ho.C. The effect of intravenous parathyrold extract on urinary $\mathrm{pH}$, blgarbonate and electrolyte excretfon. CIIn. Sc1. 19: 311-319 (1960).

99. Nordin, B.E.C., Peacock, M., WilkInson, R., The relative Importance of gut, bone and kidney in the regulation of serum calclum, In Parathyrold hormone and the calcitonins. Bd. Talmage, R.V., Mrons, P.I. Ptoc. of the fourth Parathyroid conference p. 203 (1969).

100. Oldham, s.B., Fischer, J.A., Copen, C.C., Sizemore, G.W., Arnad" C.D. Dynamics of parathýroid hormone secretion in v1tro. A. J. Had 50 : $650-657$ (1971).

101. Pitts, R.F. "The excretion of urine in the dog. An. J. Physidi. $106: 1-8(1933)$ 
102. PItts, R.F., and Alexander, R.S. The renal reabsorption of mechanism for Inorgantc phosphace in normal and actdotic dögs. Am. J. Physiol. 142: 648-652 (1944).

103. Posternak, T،M., Sutherland, E.W. Henion, W.F. Derivatives of cycilc 3'5' adenosine monophosphate. 'Blochm. Bloph' Acta. 65: $558-560(1962)$.

104. Potts, J.T., Tregear, G.W., Keutmann, H.T., Niall, H.D., Sauer, R., Deftos, L.J., Dawson, B.Fु., Hogan, M. I., Aurbach, G.D. Synthesis of blologically active N-terminal tetratrlacontapeptide of parathyrold hormone. Proc. Nat. Ac. Sc1. U.S.A. 68: 63-67 (1971).

105. Pullman, T.R., Lavender, A.R. and Rasmussen, H. Direct renal action of purified PTH extract. Endo: 67: '570-582 (1960).

106 Puschett, T.,B., Moranz, J., Kurnick, W.S. Evidence for direct action of cholecalctferol and 25-hydroxy cholcalciferol on the renal transport of phosphate, sodium and calelum. J. Clin. Invest. 51: 373 (1972).

107. Puschett, T.B., Agus, L.S., Senesky, D., Goldberg, M. Bffects of saline loading and aortic obstruction on proximal phosphate transport. An. J. Phys1ol. 223: 851-857' (1972).

108. 'Rati,, T., Sutherland, E.W. Formation of cyclic adeniné ૧Ribonucleotide by t1soue particles. J.B. Chem. 232: 10651076 (1958),

109. Ratsz, L.V., KIain, D. Stimu] ation of bone réórption,by dibutyryl cAYP In viţro. Fed. Proc. 28: 320 (19) (abstract). 
110. Racmussen, H., Tenenhouse, A. Cyclic AYP, Ca and membranes Proc. Nat. Ac. Sc. 59: 1364-1370 (1968).

111. Rasurusien, H." The Influence of parathyrold function upon the transport of calctum in 18olated saçs of rat gall Intestine. Endo. 65; 517-519 (1959).

112. 'Rasmussen, H. Pechet, M., Fast, D. Effect of dibutyryl ' -cyclic adenosine $3^{\prime} 5^{\prime}$ monophosphate, theophy 11 ine and other nucleotides upon calcium and phosphate metabolism. j. CIIn. Invest. 47: 1843-1850 (1968).

113. Rasmussen, H. Cell communtcátion, calclum Ion and cyclic. adenosine monophosphate. Sctence 170: 404-412 (1970).

114. Rebhurn, L., V11lar-Polasi, L. Stimulation of purified muscle protein kinase by cAMP and its butyrated derfvatives. Blochen and Bloph. Acta 321: 165-170 (1973).

115. Robinson;, G.A., Butcher, R.W., Sutherland, E.W.' Cyclic AMP. Ann. Rev. Bloch. 37: 149-174 (1968).

116.l Robinson, R.R., Portwood, R.M. Mechaniem of $M_{8}$ excretion by the chtcken. Am. J. Physiol. 202: 309-312 (1962).

117. 'Rouffignac, D. de;, Morel, . Y.: Mos8, W., Roine1, N. Micropuncture study of water and electrolyte movements along the loop of Henle in psamomnys with speclal reference to magnegitum, calclum and phoephorus. PfIügers Arch. '344: 309 (1973).

118. Rusadél, R.G., Carey; P.A., Rletoh, H. Stimulation of phośphate excivetion by the renal arterial Infupion of $3^{\prime} 5^{\prime}$ AMP - a possible 
mechantom of action of PTH. Calcil. Tissues Res. 2 (Sipp1.). .54 (1968).

119. Samiy, A.H.E., Briom, J.L., Globas, D.L., Kessler, R.H. and Thompson, D.D. Interrelation between renal transport systéms of magnestum and calctum. Am. J. Physiol. 198: 599-602 (1960).

120. Samiy, A.H., Hirsch, P.F., Ramsay, A.G. Locallzation of phosphaturfc effect of parathyroid hormone in the nephron of the dog. Am. J. Phystol. 208; 73-77 (1965).

121. Sherwood, L.M., Mayer, G.P., Ramberg, G.F. Jr., Kronfeld, D.S., Aurbach, G.D., Pott8, J.T. Jr. $\therefore$ Regulation of parathyrddd hormone secretion: proportional control by calcium, lack of afect of phosphate. Endo. 893: 1043-1051 (1968).

122. Shlatz, L.J., Schwartz, I.L, Kinne-Saffran, E., Rinne, R. Distri- * bution of parathyroid hormone-stimulated adenylate cyclase in plasma membranes of cells of the kidney cortex. J. Memb. Biol. 24: $131-144$ (1975).

123. Staum, B.B., Hamburger, R.T., Goldberg, M. Tracer microinfection study of renal tubular phosphate reabsorption in the rat. J. C11n: Invest. 51: $2271^{8}$ (1972).

124. Steele, T.H. Increased "urinary phosphate excretion following volume expansion in normal man. Metab. 19: 129-239 (1970).

125. Stewart, G.S., Bowen, H.F. The ur,inary phosphate excretion factor of parathyrold gland extracts: a hormone or an artefact: Bndo: 51: $80-96$ (1952). 
126. Str1ckler, T:C., Thompson, D.D., Klose, R.M. Mlcropuncture study of Inorganic" phosphate excretion in the rat. J. Clin. in:

Invest. 43: 1596-1607 (1964).

127. Sutcliffe, N.S., Martin, J.J., E1smon, D.A., P1lnyk, R.

Blinding of parathyrold hormone to bovine kidney-çortex plasma membranes. Blochem. J. 134: $913-921$ (1973).

128. Sutherland, E.D., Rall, T.W. Fractionation and character 1zatton of a cyclic adenine ribonucleotide formed by tissue part1cles. J. Biol. Chem. 232: 1077-1092 (1958).

129. Sutherland, E.D., Rall, T.W. The relation of adenosine 3'5' phosphate and phosphorylase to the actions of catecholaminẹs and other hormones. Pharmac. Rev. p. 265-299 (1960).

130. Sutton, R.A.L., Wong, N.L.M. and Dirks, J.H. Effects of parathyrold hormone on sodium and calcium transport in the dog nephron. Clinical Sclence 51: 345-351 (1976).

131. Talmage, R.V., Kraintz, F.W. Progressive changes in renal phosphate and calcium excretion in $r$ ats following parathyroldectomy or parathyrold administration. Proc. Soc. Exp.

Med: 87: 263-276 (1954).

132. Talmage, "R.V., Rraintz, F.W., Buchanan, G.D. Bffects of parathyrold extract and phosphate salts on renai calciun and phosphate. . excretion after parathyroldectomy. 'Proc., Soc. Bxp. Med. 88: 600-604 (1955).

133. Talmage, R.V. Studies on the maintenance of serum calcium levels by parathyrotd action on bone and kidrieg: Ann. N.Y. Aced. Sc1: . 64: 326-335 (1956). 
134. Talmage, R.V. and Elllott, T.R. Influence of parathyrolds on Intestinal absorption of radlocalctum and radiostrontium. Fed. Proc. 17: 160 (Abgtract) (1958).

135. Targoun1k, T.H., Rodman, T.S., Sherwood, L.M. Regulation of parathyroid hormone function in vitro: quantitative aspects of calcium and magnestum Ion control. Endo. 88: 1477-1482 (1971).

136. Thomson, D.L., Collip, J.B. The parathyroid glands. Phystol. Rev. 12: 309-383 (1932).

137. Thomson, D.D., Hiatt, H.H., Renal reabsorption of phosphate in normal human subjects and in patients with parathyroid disease. J. C1In. Invest. 36: 550-555 (1975).

138. Vurek, G.L., Pegram, W.E. Fluoremetric method for the detéfination of nanogram quantities of inulin. Analytical Blochem. 16: 409-419 (1966).

139. Walkex,A.M., Hudson, C.C. The role of the tubule in the excretion of Inorganic phosphates by the amphiblan kidney. Am. J. Phys1ó1. 118: 167-174 (1937).

140. Webster, G.D., Mann, J.B., HAlls, A.G. The effect, of phosphate infusion upon renal phosphate clearance in man: evidence for tubular phosphate secretion. Metabolism. 16: 797-814 (1967).

141. We11s, M., Lloyd, W. Hypercalcemic and hypophosphatemic effects. of dibutyryl cyclic AMP in rats after parathyrotdecţony. Endo. 84: 861-867 (1969).

142. Wen, S.L., Bransọn; R.L., Dirks, J.H. Micropincture study of renal magnesium transport in proximal and distal tubule of the dog. Am. J. Physiol. 219:' 570-576 (1970) 
82.

143. Wen, S.F. Micropuncture studles of phosphate transport in the dog. J. C1In. Inveet. 53: 143 (1974).

144. W1drow, S.H., Levinsky, N. Gँ. The effect of parathyrold extract on renal tubular calcium reabsorption in the dog. J. Clin. Imest. 14: 2151-2159 (1962).

145. Wolbach, R.A., Phloriz in and renal phosphate secretion in the spiny dog fish squalus acanthias. Am. J. Physiol. 219: 886892 (1970). 